\title{
Surface Phenomena Enhancing the Antibacterial and Osteogenic Ability of Nanocrystalline Hydroxyapatite, Activated by Multiple-Ion Doping
}

\author{
Simone Sprio, ${ }^{*}{ }^{\dagger}$ (i) Lorenzo Preti, ${ }^{\dagger \ddagger}$ Monica Montesi, ${ }^{\dagger}$ Silvia Panseri, $^{\dagger}$ Alessio Adamiano, ${ }^{\dagger}$ \\ Alberta Vandini, ${ }^{\S}$ Nicola M. Pugno, ${ }^{+, \|, \perp} \perp^{\circ}$ and Anna Tampieri ${ }^{\dagger}$ \\ ${ }^{\dagger}$ Institute of Science and Technology for Ceramics-National Research Council (ISTEC-CNR), Faenza 48018, Italy \\ ${ }^{\ddagger}$ Laboratory of Bio-inspired \& Graphene Nanomechanics, Department of Civil, Environmental and Mechanical Engineering, \\ University of Trento, Via Mesiano 77, 38123 Trento, Italy \\ ${ }^{\S}$ Institute of Microbiology, University of Ferrara, Ferrara 44121, Italy \\ ${ }$ School of Engineering and Materials Science, Queen Mary University of London, Mile End Road, London E1 4NS, U.K. \\ ${ }^{\perp}$ Ket-Lab, Edoardo Amaldi Foundation, Via del Politecnico, 00133 Rome, Italy
}

\begin{abstract}
The present work describes a novel nanocrystalline, multidoped hydroxyapatite featuring excellent eukaryotic versus prokaryotic cell selectivity, attested by excellent osteoinductive character and evaluated with human stem cells, and anti-infective ability, tested against different pathogens. Physicochemical analysis and transmission electron microscopy (TEM)/scanning STEM observations highlighted that such enhanced biological features are related to the lower crystallinity level and increased surface charge of hydroxyapatite, both induced by multiple-ion doping. Specifically, the lattice substitution of $\mathrm{Ca}^{2+}$ with $\mathrm{Zn}^{2+}$ promotes the segregation of $\mathrm{Ca}^{2+}$ and doping $\mathrm{Mg}^{2+}$ cations to a less-ordered surface layer, thus promoting dynamic ion

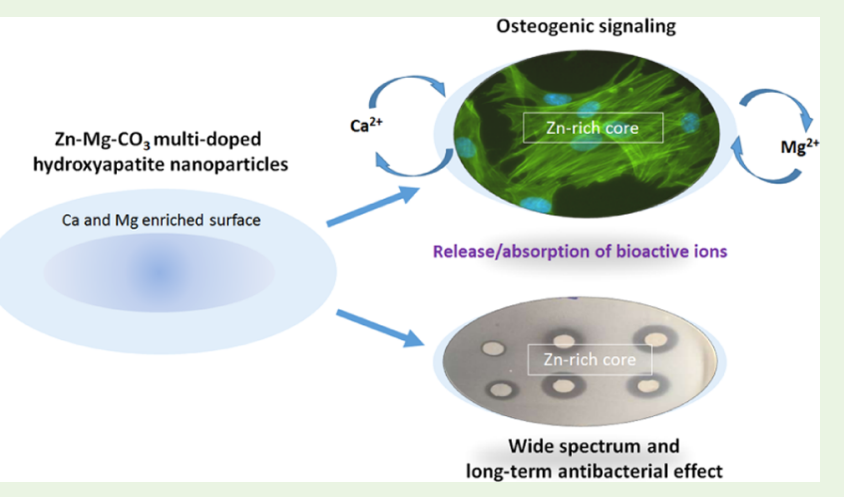
absorption/release acting as bioactive signals for cells and exerting an antiproliferative effect on all tested pathogens. These findings open the design of new biodevices, combining regenerative ability and effective microbial inhibition without using any antibiotic drugs. This is extremely important to circumvent bacterial resistance to antibiotics, which is today considered as one of the biggest threats to global health.
\end{abstract}

KEYWORDS: nanocrystalline apatites, ion exchange, zinc, magnesium, bone regeneration, antimicrobial effect

\section{INTRODUCTION}

Implantation of medical devices is a frequent surgical practice which, however, is a gateway for pathogen contamination and infections that are often at the basis of the implant failure. Nowadays, this problem raises great concern, mostly due to the bacterial resistance to antibiotic drugs, which is increasing at an alarming rate. Owing to this, it is expected that in the coming decades, nosocomial infections will not be effectively treated by current drug-based protocols, thus leading to negative impact on the clinical outcome of a steadily growing number of patients, particularly those subjected to orthopedic prosthetic surgery, in terms of longer hospital stays, higher medical costs, and increased mortality. ${ }^{1,2}$ In this scenario, the development of drug-free solutions as an alternative to systemic and intensive administration of antibiotics and associated with therapeutically effective biomaterials is increasingly demanded. Most of these solutions are based on the functionalization of biomaterials with elements having antibacterial properties, prominently silver or heavy metal nanoparticles. ${ }^{3}$ However, if overdosed, these materials can result into cytotoxic and genotoxic effects on healthy cells, and the correct dosage and distribution of antibacterial nanoparticles are quite difficult to define and apply. ${ }^{4-6}$ Striving to obtain more biocompatible and safer compounds, calcium phosphates ( $\mathrm{CaPs}$ ) are unanimously considered as elective materials to develop devices for bone regeneration because of excellent biocompatibility and osteoconductivity given by their close similarity with the mineral bone composition. A recent study highlighted the potential of $\mathrm{CaPs}$ as potential antibacterial agents, both against various Gram-positive and Gram-negative strains, including their multidrug-resistant analogues. ${ }^{7}$ Previous studies reported the development of hydroxyapatite (HA) doped with ions such as silver, copper, gallium, or zinc to improve antibacterial properties and, particularly, in the case of zinc, to provide

Received: June 20, 2019

Accepted: September 24, 2019

Published: September 24, 2019 
additional therapeutic effects. ${ }^{8-11}$ Multiple-ion doping is a major characteristic of the natural bone tissue, particularly, $\mathrm{Mg}^{2+}$ and $\mathrm{CO}_{3}{ }^{2-}$ ions are abundant (i.e. in extent $\sim 6 \mathrm{~mol} \%$ for $\mathrm{Mg}$ and 5-6 wt $\%$ for $\mathrm{CO}_{3}{ }^{2-}$ ) in the immature bone as they promote the formation of new bone mineral nuclei. ${ }^{12,13}$ Thus, previous studies showed that synthetic ion-doped HA exhibits enhanced bioactivity, particularly when doped with $\mathrm{Mg}^{2+}$ and $\mathrm{CO}_{3}{ }^{2-}$ ions by wet synthesis methods. ${ }^{12,14,15} \mathrm{~A}$ previous study reported that multidoped $\mathrm{HA}$ including $\mathrm{Ga}^{3+}$ ions was effective in providing good osteogenic ability and anti-infective protection. ${ }^{16}$ However, gallium is a toxic element not naturally present in the human body, and its occurrence might give rise to adverse reactions when administered in inappropriate doses.

The doping of $\mathrm{HA}$ with $\mathrm{Zn}^{2+}$ ions - present in the natural bone as a trace element, that is, $\sim 0.2 \mathrm{wt} \%{ }^{17}$ was extensively studied, given its ability to substitute $\mathrm{Ca}^{2+}$ ions in the HA structure and to confer improved effects on cells, such as for the restoration of bone metabolism during osteoporosis and also to provide antibacterial properties. ${ }^{8,18}$ Zinc is of great importance for many metabolic processes and is at the same time a relatively harmless element; ${ }^{19}$ thus, many studies on $\mathrm{Zn}$ doped HA concerned $\mathrm{Zn}$ doping in much higher amounts with respect to the physiological levels. $8,20,21$

The present work describes a nanocrystalline HA, prepared for the first time by multiple doping with $\mathrm{Zn}^{2+}, \mathrm{Mg}^{2+}$, and $\mathrm{CO}_{3}{ }^{2-}$ ions, to promote osteo-differentiation and to give additional protection against microbial proliferation. The effect of the doping ions on the physicochemical properties and, in turn, on the HA bioactivity is evaluated in terms of proliferation and osteogenic differentiation of human adipose-derived stem cells. In a parallel experiment, in vitro cultures of four pathogens, that is, Gram-positive bacteria Staphylococcus aureus, Gram-negative bacteria Escherichia coli, Pseudomonas aeruginosa, and yeast Candida albicans, which are among the most common agents involved in nosocomial infections, ${ }^{22-26}$ are carried out to assess the antimicrobial ability of the new materials. This latter analysis is carried out on both as-obtained and aged materials to evaluate bacterial inhibition over a relatively long time lapse, relevant to face the early critical postoperative period. The obtained results report alteration of the crystal structure of $\mathrm{HA}$ induced by the incorporation of $\mathrm{Zn}^{2+}$ and the other doping ions in the HA lattice, yielding enhanced surface activity in multidoped powders with respect to undoped HA and able to influence the fate of cell and bacteria through biochemical signaling.

\section{MATERIALS AND METHODS}

2.1. Material Synthesis. Undoped and ion-doped HA phases were synthesized by a neutralization method in aqueous environment using ultrapure water $\left(0.22 \mathrm{mS}, 25^{\circ} \mathrm{C}\right)$ to prevent the incorporation of undesired foreign ions in the final product. Undoped HA was synthesized as a reference material by preparing an aqueous suspension of calcium hydroxide $\left[\mathrm{Ca}(\mathrm{OH})_{2}\right.$, Sigma-Aldrich, 95\% purity], $10 \mathrm{~g}$ in $150 \mathrm{~mL}$, and then neutralized with a solution of phosphoric acid $\left(\mathrm{H}_{3} \mathrm{PO}_{4}\right.$, Fluka, $85 \%$ purity), $9.72 \mathrm{~g}$ in $100 \mathrm{~mL}$ by slow dripping (dripping rate $=1 \mathrm{drop} / \mathrm{s}$ ). To achieve $\mathrm{Zn}^{2+}$ and $\mathrm{Mg}^{2+}$ ion doping in the apatite structure, zinc nitrate $\left[\mathrm{Zn}\left(\mathrm{NO}_{3}\right)_{2}\right.$, SigmaAldrich] and magnesium chloride hexahydrate $\left(\mathrm{MgCl}_{2} \cdot 6 \mathrm{H}_{2} \mathrm{O}\right.$, SigmaAldrich, $99.5 \%$ purity) were used. To dope the apatite with $\mathrm{CO}_{3}{ }^{2-}$ ions, a solution of calcium bicarbonate $\left(\mathrm{NaHCO}_{3}\right.$, Sigma-Aldrich) was dropped in the alkaline suspension simultaneously with the $\mathrm{H}_{3} \mathrm{PO}_{4}$ solution. In all the syntheses, the $\mathrm{Ca} / \mathrm{P}$ ratio was set to 1.67 , that is, equal to that of stoichiometric HA. Single-doped HAs were prepared with different $\mathrm{Zn}$ contents (i.e., Zn-HA-1 and Zn-HA-2), whereas multidoped $\mathrm{HA}$ was obtained by adding $\mathrm{Zn}, \mathrm{Mg}$, and $\mathrm{CO}_{3}$ ions (i.e., $\mathrm{Zn}-\mathrm{MCHA}$ ). The synthesis process was carried out at $40{ }^{\circ} \mathrm{C}$ to limit the HA crystal growth. The concentrations of the various ions are indicated as $X_{\mathrm{Zn}}, X_{\mathrm{Mg}}$ and $X_{\mathrm{CO}_{3}}$ [i.e., the molar ratios $\mathrm{Zn} /(\mathrm{Ca}+$ $\mathrm{Mg}+\mathrm{Zn}), \mathrm{Mg} /(\mathrm{Ca}+\mathrm{Mg}+\mathrm{Zn})$, and $\mathrm{CO}_{3} /\left(\mathrm{CO}_{3}+\mathrm{PO}_{4}\right)$, respectively]. Nominal concentrations for the various doping ions are Zn-HA-1: $X_{\mathrm{Zn}}=0.05$; Zn-HA-2: $X_{\mathrm{Zn}}=0.10$; Zn-MCHA: $X_{\mathrm{Zn}}=0.05$, $X_{\mathrm{Mg}}=0.05$, and $X_{\mathrm{CO}_{3}}=0.15$.

After the end of the dropping, the suspension was maintained under stirring for $2 \mathrm{~h}$ to complete the reaction and homogenize the product. Then, the stirring was stopped, and the suspension was left overnight for maturation and sedimentation of the product. Then, the supernatant liquid was removed, and the solid product was separated by the residual fluid by centrifugation, repeatedly washed in bidistilled water, and finally dried at $40{ }^{\circ} \mathrm{C}$ for $64 \mathrm{~h}$. The dried powders were manually milled, sieved below $106 \mu \mathrm{m}$, and stored in a dry environment for further analysis.

2.2. Material Characterization. The phase composition of the as-obtained materials was obtained by X-ray diffraction (XRD) with a D8 ADVANCE (Bruker, Karlsruhe, Germany) diffractometer using $\mathrm{Cu} \mathrm{K} \alpha$ radiation $(\lambda=1.54178 \AA)$ generated at $40 \mathrm{kV}$ and $40 \mathrm{~mA}$, a counting time of $0.5 \mathrm{~s}$, and a step size of $0.02^{\circ} 2 \theta$. Cell parameters and crystallite size were assessed by the full profile analysis of the XRD spectra (TOPAS 5, Bruker, Karlsruhe, Germany).

Infrared spectroscopy was performed on the as-obtained powders by using a Nicolet 380 FTIR spectrometer (Thermo Fisher Scientific Inc., Waltham, MA, US). The Fourier transform infrared (FTIR) spectra were recorded on small pellets obtained by mixing $1 \mathrm{mg}$ of the sample powder with $150 \mathrm{mg}$ of anhydrous potassium bromide $(\mathrm{KBr})$. The mixture was pressed at $10^{8} \mathrm{~g}$ pressure into $7 \mathrm{~mm}$ diameter disks. Before the acquisition of the FTIR spectra, the disks were heated at $100{ }^{\circ} \mathrm{C}$ for $24 \mathrm{~h}$ to expel the physically adsorbed water. A pure $\mathrm{KBr}$ disk was used as blank.

The carbonate content was evaluated by thermogravimetric analysis (TGA) of dried samples $(\sim 10 \mathrm{mg})$ in the range of $600-1100{ }^{\circ} \mathrm{C}^{27}$ using a Stanton STA 1500 (Stanton, London, UK) analyzer with a heating rate of $10^{\circ} \mathrm{C} / \mathrm{min}$.

The chemical analysis was performed on dried samples $(\sim 20 \mathrm{mg})$ using inductively coupled plasma atomic emission spectroscopy (ICP-OES, Agilent 5100, United States) and primary standards (1000 ppm, Fluka). The samples were dissolved into $2 \mathrm{~mL}$ of nitric acid then diluted in $100 \mathrm{~mL}$ of MilliQ water.

Microscopic investigation of the powders was carried out by field emission gun scanning electron microscopy (SEM) (Sigma NTS $\mathrm{GmbH}$, Carl Zeiss, Oberkochen, Germany). The samples were placed on an aluminum stub and covered with a thin gold layer to improve electrical conductivity.

The nanoparticle morphology and size in the dry state were analyzed using transmission electron microscopy (TEM, FEI Tecnai F20) equipped with a Schottky emitter and operating at 120 and 200 $\mathrm{keV}$. The powder $(10 \mu \mathrm{L})$ was suspended in $5 \mathrm{~mL}$ of isopropanol and treated with ultrasound. A droplet of the resulting finely dispersed suspension was evaporated at room temperature and atmospheric pressure on a holey carbon film supported by a copper grid. The nanoparticle nanostructure was investigated by high-resolution TEM, and energy-dispersive system (EDS) profiling with a spatial resolution of $3 \mathrm{~nm}$ was recorded by scanning TEM (STEM) at $200 \mathrm{kV}$.

The specific surface area (SSA) of the powders was measured by the nitrogen adsorption method, following the Brunauer-EmmettTeller model (Sorpty 1750, Carlo Erba, Milan, Italy).

The release of ions was evaluated by immersing tablets obtained with the various HA powders ( $1 \mathrm{~g}$ each) consolidated by cold isostatic pressing at 2500 bar with a final dimension of $20.5 \mathrm{~mm} \varnothing \times 2 \mathrm{~mm}$ height, a superficial area of $7.9 \mathrm{~cm}^{2}$, and an average residual porosity of $52 \%$ into $5 \mathrm{~mL}$ of pH 7.4 buffer solution (Ca and Mg-free Hank's balanced salt solution) kept at $37^{\circ} \mathrm{C}$ and gently shaken at $200 \mathrm{rpm}$. At scheduled times (i.e., after 1, 2, 3, 7, 11, and 15 days), the solution was removed and $5 \mathrm{~mL}$ of fresh solution was added to the tablets. Similar experiments were carried out by immersing the tablets in 

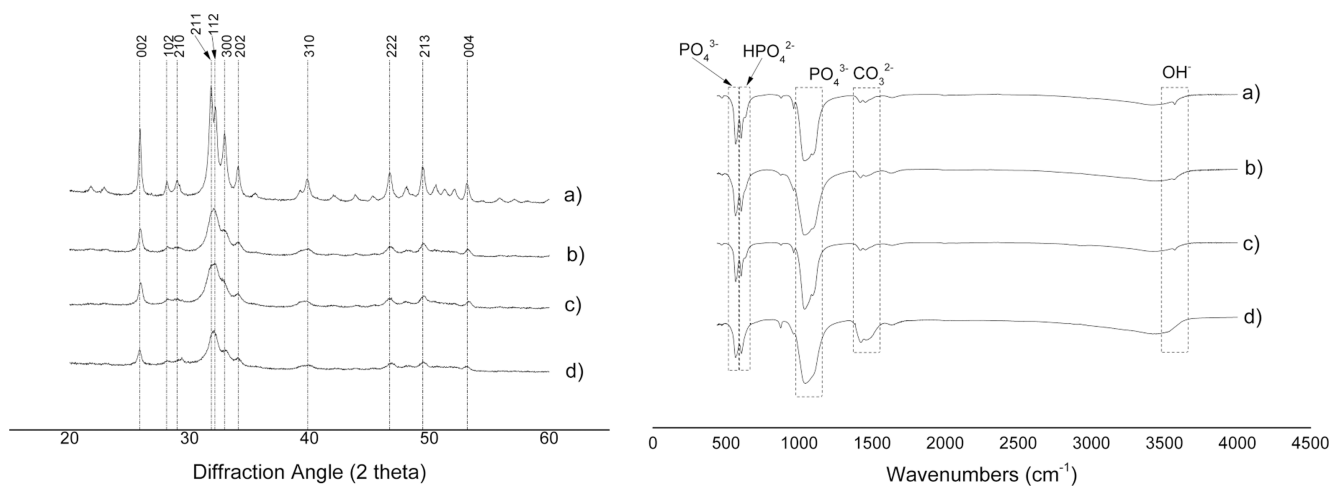

Figure 1. Left: XRD patterns of the studied materials. (a) HA, (b) Zn-HA-1, (c) Zn-HA-2, and (d) Zn-MCHA. Right: FTIR absorption spectra: (a) HA, (b) Zn-HA-1, (c) Zn-HA-2, and (d) Zn-MCHA.

osteogenic medium [minimum Eagle's essential medium $(\alpha \mathrm{MEM})$ supplemented with $10 \% \mathrm{FBS}, 1 \%$ penicillin/streptomycin $100 \mathrm{U}$. $\mathrm{mL}^{-1} / 100 \cdot \mu \mathrm{g} \cdot \mathrm{mL}^{-1}, 10 \mathrm{mM} \beta$-glycerophosphate, $50 \mu \mathrm{g} / \mathrm{mL}$ ascorbic acid, and $100 \mathrm{nM}$ dexamethasone]. The liquids containing the ions released after the prefixed times were analyzed by ICP-OES, in triplicate, for the quantitative determination of $\mathrm{Ca}, \mathrm{Mg}$, and $\mathrm{Zn}$.

The $\zeta$-potential distribution of dried powders suspended in $\mathrm{N}$-(2hydroxyethyl)piperazine- $N^{\prime}$-ethanesulfonic acid buffer at $\mathrm{pH} 7.4$ was measured by dynamic light scattering with a Zetasizer Nano ZS instrument (Malvern Ltd., Worcestershire, U.K.) and quantified by laser Doppler velocimetry as electrophoretic mobility using a disposable electrophoretic cell (DTS1061, Malvern Ltd., Worcestershire, U.K.). Twenty runs of $3 \mathrm{~s}$ each were collected in each measurement.

2.3. Cell Culture. Human adipose-derived mesenchymal stem cells (ASCs) were purchased from ATCC and cultured following the company indications. ASCs were seeded at $5.0 \times 10^{3} \mathrm{cells} / \mathrm{cm}^{2}$ and cultured in osteogenic medium ( $\alpha$ MEM supplemented with $10 \%$ FBS, $1 \%$ penicillin/streptomycin $100 \mathrm{U} \cdot \mathrm{mL}^{-1} / 100 \mu \mathrm{g} \cdot \mathrm{mL}^{-1}, 10 \mathrm{mM} \beta$ glycerophosphate, $50 \mu \mathrm{g} / \mathrm{mL}$ ascorbic acid, and $100 \mathrm{nM}$ dexamethasone). Twenty four hours after the cell seeding, two different concentrations ( 50 and $500 \mu \mathrm{g} / \mathrm{mL}$ ) of selected apatites ( $\mathrm{HA}$ as the control, Zn-HA-1, and Zn-MCHA) were added and the cells left in culture for 14 days.

2.4. Cell Viability Assay. After $1,3,7$, and 14 days, cell viability was investigated by MTT reagent (3-(4,5-dimethylthiazol-2-yl)-2,5diphenyltetrazolium bromide) assay. MTT $(20 \mu \mathrm{L}, 5 \mathrm{mg} / \mathrm{mL})$ was added into each well; $2 \mathrm{~h}$ later, $200 \mu \mathrm{L}$ of dimethylsulfoxide was added to the cells, and absorbance was detected at $570 \mathrm{~nm}$ (A570) using a Multiskan FC Microplate Photometer (Thermo Fisher Scientific). This absorbance is directly proportional to the number of metabolically active cells. Mean values of absorbance were determined. Three samples per group were analyzed.

2.5. Cell Morphology Evaluation. After 3 days of culture, cell cultures were washed in $1 \times$ PBS for $5 \mathrm{~min}$, fixed in $4 \%(\mathrm{w} / \mathrm{v})$ paraformaldehyde for $15 \mathrm{~min}$, and permeabilized with $0.1 \%(\mathrm{v} / \mathrm{v})$ Triton X-100 for 5 min. Fluorescein isothiocyanate-conjugated phalloidin (38 nM, Invitrogen) was added for $20 \mathrm{~min}$ at room temperature in the dark, and 4',6-diamidino-2-phenylindole DAPI $300 \mathrm{nM}$ (Invitrogen) for 5 min was used for nuclear staining. Images were acquired by an Inverted Ti-E fluorescence microscope (Nikon). The analysis was performed for all groups at both concentrations.

2.6. Quantitative Real-Time Polymerase Chain Reaction. After 7 and 14 days, the total RNA of cells was extracted and purified by Tri Reagent, followed by the Direct-zol RNA MiniPrep kit (Zymo Research) according to manufacturer's instructions. RNA (500 ng) were reverse transcribed to cDNA using the High-Capacity cDNA Reverse Transcription Kit, according to manufacturer's instructions (Life Technologies). Alkaline phosphatase (ALP, HS01029144) and 3-phosphate dehydrogenase (HS99999905) genes (Life Technologies) were quantified by the StepOne Real-Time PCR System (Applied Biosystems). Experiment was done in triplicate using three technical replicates for each experiment. Data were collected using the StepOne software (v.2.2.2), and relative quantification was performed using the comparative threshold $\left(C_{\mathrm{t}}\right)$ method $\left(\Delta \Delta C_{\mathrm{t}}\right)$, where the relative gene expression level equals $2^{-\Delta \Delta C_{\mathrm{t}} .}{ }^{16} \mathrm{HA}$ samples were used as the calibrator.

2.7. Immunofluorescence Analysis. After 7 days, the cells were fixed in $4 \%(\mathrm{w} / \mathrm{v})$ paraformaldehyde, blocked with $20 \%$ normal goat serum, and permeabilized with $0.1 \%(\mathrm{v} / \mathrm{v})$ Triton $\mathrm{x}-100$. The cells were incubated overnight at $4{ }^{\circ} \mathrm{C}$, with antibodies anti-runt-related transcription factor 2 (RUNX2) and collagen I (COL-1) (Abcam), followed by incubation with secondary antibodies Alexa Fluor 488 goat anti-rabbit (Molecular Probes) and Cy3 sheep anti-mouse (Molecular Probes) for $45 \mathrm{~min}$ at room temperature. Cell nuclei were stained with DAPI $300 \mathrm{nM}$. Images of one sample per group were acquired by an Inverted Ti-E fluorescence microscope (Nikon).

2.8. Statistical Analysis. Analysis of the effect of nanopowders on cell viability and gene expression was made by two-way analysis of variance, followed by Bonferroni's post hoc test by the GraphPad Prism software (version 6.0) with statistical significance set at $p \leq$ 0.05 . Results were expressed as mean \pm standard error of the mean.

2.9. Antimicrobial Tests. To assess the effect of ion doping on the antimicrobial properties of HA, specific tests were performed on the multidoped ZnMCHA, single-doped Zn-HA-1 and Zn-HA-2, and the undoped HA taken as the control. The selected materials were tested against pathogenic yeasts (C. albicans) and against potentially pathogenic bacteria, such as Gram-negative (E. coli and P. aeruginosa) and Gram-positive bacteria (S. aureus). Two subcultures from the stock culture by streaking onto tryptone soy agar (for bacteria) and onto Sabouraud dextrose agar (for yeast Candida) were prepared and incubated overnight. From one subculture (the working culture), a loop full of bacterial cells was transferred into the diluent and suspended. Each microbial test suspension was prepared by taking 1 $\mathrm{mL}$ of the diluent (tryptone sodium chloride solution) using a mechanical shaker. The number of cells in the microbial suspension was adjusted in the range from $5.3 \times 10^{6}$ to $6.7 \times 10^{6} \mathrm{cfu} / \mathrm{mL}$ for bacteria and $6.0 \times 10^{5} \mathrm{cfu} / \mathrm{mL}$ for Candida by turbidimetry. For the determination of the bactericidal effect, $400 \mu \mathrm{L}$ of microbial suspension was added to tablets prepared in the same manner as for ion-release tests. The antibacterial tests were carried out in triplicate on two different sets of materials: the first set (coded as PRISTINE) was used as synthesized; the second set (coded as AGED) was used after aging the apatite tablets into $\mathrm{pH}=7.4$ buffer solution (Ca- and Mg-free Hank's balanced salt solution) for 14 days, that is, in the same medium used for the analysis of ion release. After every contact time, through dilution, the total viable count was calculated and expressed in $\mathrm{cfu} / \mathrm{mL}$. The reduction in viability was calculated as $N \times 10^{-1} N_{a}$ where $N$ and $N_{a}$ are the bacterial concentrations $(\mathrm{cfu} / \mathrm{mL})$ at the beginning and after the test. 
Table 1. Crystallographic Data of the Studied Materials

\begin{tabular}{lccccccccc}
\multicolumn{1}{c}{ sample } & $a(\AA)$ & $c(\AA)$ & $c / a$ & cell vol $\left(\AA^{3}\right)$ & $D_{\text {av }}(\mathrm{nm})$ & $D_{300}(\mathrm{~nm})$ & $D_{002}(\mathrm{~nm})$ & shape factor & splitting factor \\
HA & $9.432(1)$ & $6.895(1)$ & $0.731(1)$ & $531.2 \pm 0.1$ & $21.3 \pm 2.1$ & $22.8 \pm 0.4$ & $56.0 \pm 1.5$ & 2.46 \\
Zn-HA-1 & $9.423(5)$ & $6.887(4)$ & $0.730(9)$ & $529.7 \pm 0.2$ & $15.4 \pm 1.2$ & $16.7 \pm 0.8$ & $31.2 \pm 0.9$ & 1.87 \\
Zn-HA-2 & $9.404(9)$ & $6.885(5)$ & $0.728(3)$ & $527.3 \pm 0.1$ & $13.1 \pm 1.7$ & $16.7 \pm 1.0$ & $31.7 \pm 0.8$ & 1.90 \\
Zn-MCHA & $9.378(6)$ & $6.880(5)$ & $0.733(6)$ & $524.1 \pm 0.2$ & $11.6 \pm 1.6$ & $18.2 \pm 1.1$ & $25.6 \pm 0.8$ & 3.58 & 1.41 \\
\hline
\end{tabular}

Table 2. Ion Content in the As-Obtained Materials with Respect to the Nominal Amount Introduced in the Reaction Vessel

\begin{tabular}{lccccccccc}
\multicolumn{1}{c}{ samples } & $\mathrm{Ca} / \mathrm{P}(\mathrm{mol})$ & $\mathrm{Ca}$ wt $\%$ & nominal $X_{\mathrm{Mg}}$ & actual $X_{\mathrm{Mg}}$ & nominal $X_{\mathrm{Zn}}$ & actual $X_{\mathrm{Zn}}$ & nominal $X_{\mathrm{CO}_{3}}$ & actual $X_{\mathrm{CO}_{3}}$ & $\mathrm{CO}_{3}$ wt $\%$ \\
HA & 1.69 & 36.5 & & & & & & 0.070 & 2.41 \\
Zn-HA-1 & 1.76 & 34.2 & & & 0.05 & 0.049 & & 0.084 \\
Zn-HA-2 & 1.59 & 25.6 & & & 0.10 & 0.09 & & 0.093 \\
Zn-MCHA & 1.71 & 30.4 & 0.15 & 0.071 & 0.05 & 0.040 & 0.15 & 0.135 & 5.17 \\
\hline
\end{tabular}

\section{RESULTS}

3.1. Physicochemical Characterization. XRD analysis (Figure 1a) confirms that the HA phase is the only crystalline component (PDF card \#09-0432) of all the as-obtained materials. The XRD spectra of the ion-doped materials are characterized by broader patterns as compared with the undoped HA. This effect can be ascribed to a reduction of the crystalline domain size because of the presence of doping $\mathrm{Mg}^{2+}$ and $\mathrm{Zn}^{2+}$ ions as substitutes for $\mathrm{Ca}^{2+}$ and of $\mathrm{CO}_{3}{ }^{2-}$ ions for $\mathrm{PO}_{4}{ }^{3-}$, as also observed in previous works. ${ }^{10,14,20,28,29}$

FTIR spectra (Figure 1b) confirm the presence of the characteristic absorption bands of the phosphate group at 980-1100 and 560-600 $\mathrm{cm}^{-1}$ typical of the HA phase. The FTIR adsorption bands appear weakly resolved, typical for lowcrystalline materials, as confirmed by the splitting factors reported in Table 1. In this respect, the multidoped HA exhibits the lowest splitting factor. FTIR analysis also denotes the presence of $\mathrm{CO}_{3}{ }^{2-}$ groups in all doped HA, attested by the presence of absorption bands at $\sim 1450,1430$, and $870 \mathrm{~cm}^{-1}$, belonging to $\mathrm{CO}_{3}$ groups substituting $\mathrm{PO}_{4}{ }^{3-}$ ions in the apatite lattice (i.e., B-carbonation). The undoped HA also shows typical bands related to $\mathrm{B}$ carbonation; such a spontaneous incorporation of $\mathrm{CO}_{3}{ }^{2-}$ ions is commonly ascribed to the dissolution of atmospheric carbon dioxide into the mother solution during powder synthesis, as previously observed by several works. ${ }^{14,27}$ B-carbonation is abundant in the newly formed and immature bone and is considered as a key aspect for the HA bioactivity because it strongly increases its solubility at physiological environment and promotes osteoblast cell adhesion. ${ }^{21}$ In comparison with the undoped HA, FTIR analysis also highlights the reduction of the $\mathrm{OH}^{-}$ absorption band at $3570 \mathrm{~cm}^{-1}$ in single-substituted Zn-HA-1 and Zn-HA-2 and, in higher extent, in Zn-MCHA (similar content of $\mathrm{Zn}^{2+}$ as $\mathrm{Zn}-\mathrm{HA}-1$ but also containing $\mathrm{Mg}^{2+}$ and $\mathrm{CO}_{3}{ }^{2-}$ ions). This finding is consistent with a previous study highlighting a direct correlation between the crystal size decrease and the hydroxylation extent in nanocrystalline HA. ${ }^{22}$ In our materials, a possible mechanism explaining the decrease of the hydroxyl band is the charge compensation for the carbonate ion uptake in the substitution of a phosphate group, resulting in lack of a negative charge. The charge neutrality can be restored by the concurrent elimination of one $\mathrm{Ca}^{2+}$ and $\mathrm{OH}^{-}$ion for every $\mathrm{PO}_{4} \leftrightarrow \mathrm{CO}_{3}$ exchange.

Crystallographic data obtained by the full profile analysis of the XRD patterns in Figure 1 are reported in Table 1. Specifically, the ion-doped HA powders show lattice deformation, with $a$ and $c$ parameters steadily decreasing with higher $\mathrm{Zn}$ content, particularly when $\mathrm{Mg}^{2+}$ ions were also introduced, thus confirming the general trend observed in previous studies where the doping was only with $\mathrm{Zn}^{2+}$ ions. ${ }^{21,28}$ The reduction of the cell volume (up to $-1.3 \%$ in $\mathrm{Zn}-\mathrm{MCHA}$ ) and of the average crystallite size is related to alteration of the interatomic distances, which can be ascribed to the smaller atomic radius of the doping ions with respect to calcium (i.e., $\mathrm{Zn}^{2+}=88 \mathrm{pm}$ and $\mathrm{Mg}^{2+}=86 \mathrm{pm}$ compared with $\mathrm{Ca}^{2+}=114$ $\mathrm{pm}$ ) and phosphate ions (i.e., $\mathrm{CO}_{3}{ }^{2-}=178 \mathrm{pm}$ compared with $\mathrm{PO}_{4}{ }^{3-}=238 \mathrm{pm}$ ). In comparison with Ren et al. who prepared $\mathrm{Zn}$-doped HAs at $90{ }^{\circ} \mathrm{C}$, ${ }^{21}$ the adoption of biomimetic conditions for our synthesis induced very limited crystal growth (1 order of magnitude smaller), thus with a specific surface much closer to the natural bone. ${ }^{30,31}$ The crystalline domain size along the two orthogonal axes of the hexagonal HA lattice was measured by analyzing the broadening of the (300) and (002) reflections $(d \approx 2.72$ and $\sim 3.44 \AA$, respectively; see $D_{300}$ and $D_{002}$ in Table 1$)$. The undoped HA shows a marked crystal growth along the $c$ axis, typical of the mature bone tissue, ${ }^{17}$ and conversely, the ion-doped HA powders show a reduced crystal anisotropy and a shape factor (i.e., $D_{300} / D_{002}$ ) closer to 1 . This effect is more evident in the $\mathrm{Zn}$-MCHA phase as a result of multiple-ion substitutions increasing the crystal disorder and possibly limiting the crystal growth along the $00 l$ direction. Therefore, our synthesis conditions can yield multidoped HAs mimicking the crystal state of the immature bone tissue, which is metabolically very active; $^{17,31}$ hence, it may represent a source of enhanced bioactivity.

Chemical analysis by ICP-OES, reported in Table 2, confirms the presence of $\mathrm{Mg}^{2+}$ and $\mathrm{Zn}^{2+}$ ions in the as-obtained materials. In $\mathrm{Zn}-\mathrm{HA}-1$ and $\mathrm{Zn}-\mathrm{HA}-2$, the yield of $\mathrm{Zn}$ doping is above $90 \%$. In the case of $\mathrm{Zn}-\mathrm{MCHA}$ codoped with $\mathrm{Zn}^{2+}$ and $\mathrm{Mg}^{2+}$, the yield of zinc entering is reduced and part of the introduced $\mathrm{Mg}^{2+}$ ions $(\sim 7 \mathrm{~mol} \%)$ is as well included in the HA structure. The extent of $\mathrm{Mg}$ entered in $\mathrm{Zn}-\mathrm{MCHA}$ is comparable with that obtained in a previous study, where $\mathrm{Mg}-\mathrm{CO}_{3}$-doped $\mathrm{HA}$ was prepared by a similar synthesis route; ${ }^{15}$ therefore, we can infer that the doping with $\mathrm{Zn}^{2+}$ ions does not alter the capability of $\mathrm{Mg}^{2+}$ ions to enter in the HA structure as a dopant. The decrease of the calcium content with the increase of $\mathrm{Zn}$ doping sustains the hypothesis that $\mathrm{Zn}^{2+}$ ions substitute $\mathrm{Ca}^{2+}$ in the lattice. Regarding $\mathrm{Mg}^{2+}$, previous studies reported that a lattice substitution of up to $\sim 10 \%$ can be obtained in Mg-doped HA phases; ${ }^{12}$ however, in the case of codoping with divalent cations, both $\mathrm{Zn}^{2+}$ and $\mathrm{Mg}^{2+}$ are expected to compete to occupy the same crystal sites of 


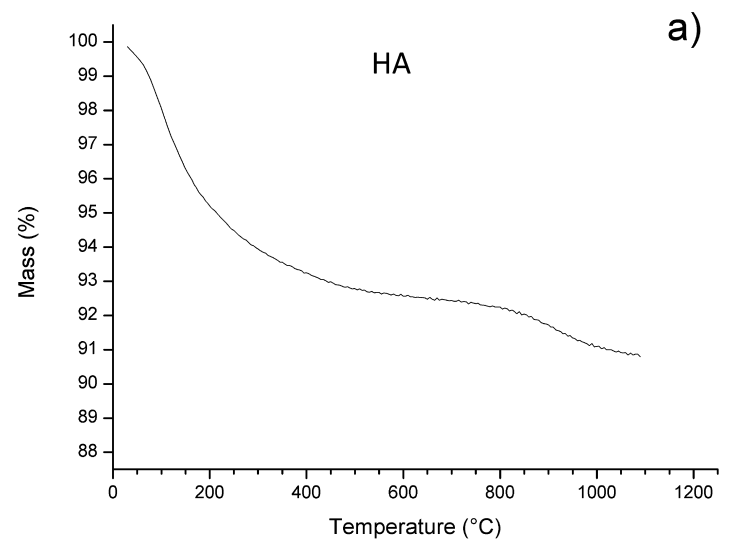

c)

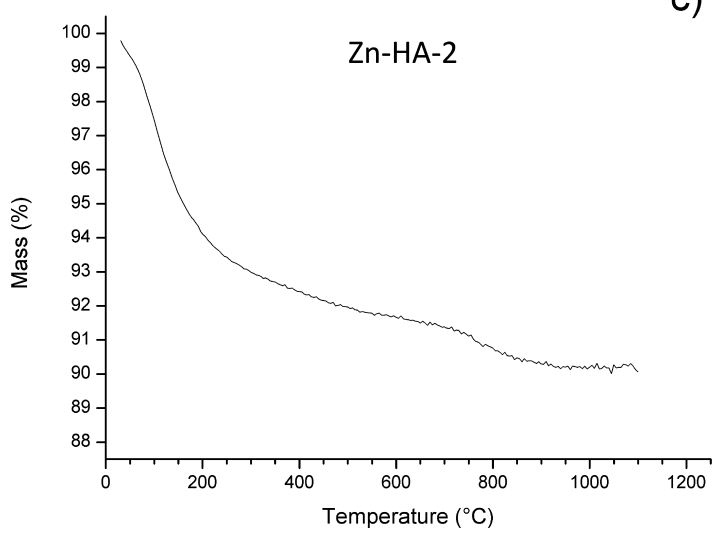

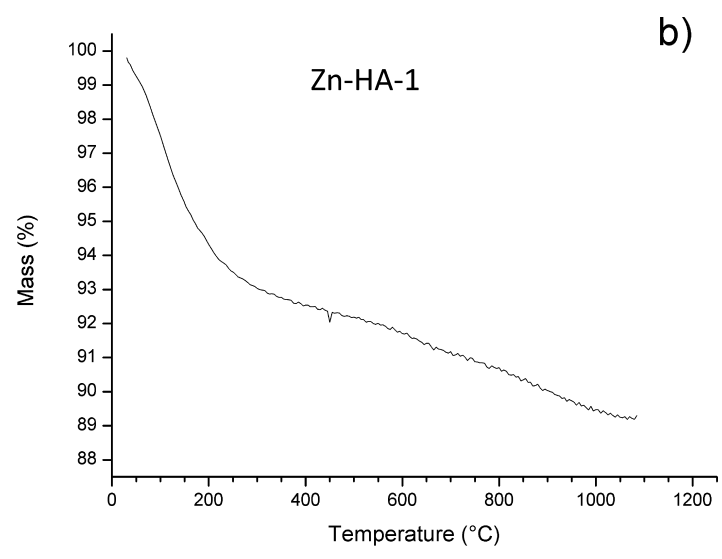

b)

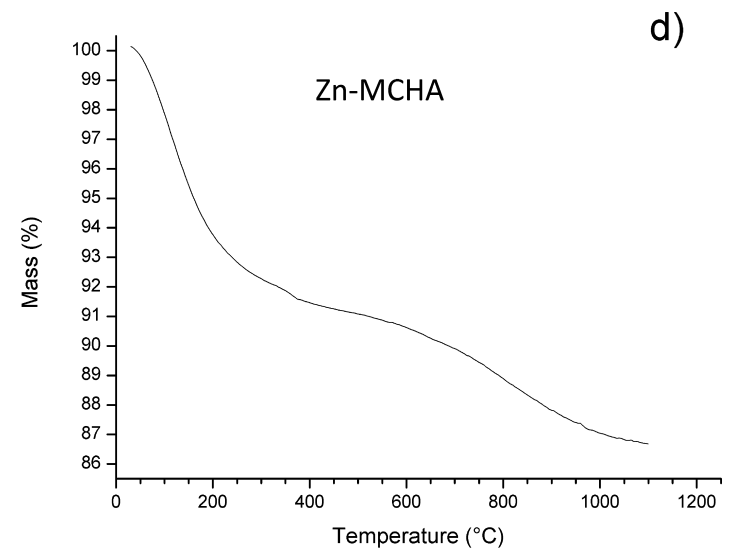

Figure 2. TG spectra of: (a) HA, (b) Zn-HA-1, (c) Zn-HA-2, and (d) Zn-MCHA.

$\mathrm{Ca}^{2+}$, and therefore it can be hypothesized that in $\mathrm{Zn}-\mathrm{MCHA}$, at least a fraction of doping ions does not occupy substitutional positions in the HA lattice sites.

TGA (Figure 2) shows that all of the studied materials undergo a weight loss of $\sim 10-15 \%$ upon heating up to 1100 ${ }^{\circ} \mathrm{C}$. Typically, all TG spectra show a weight loss of $\sim 6-7 \mathrm{wt} \%$ up to $\sim 300{ }^{\circ} \mathrm{C}$ (Table 3), which was found to be the upper

Table 3. Weight Loss (\%) Recorded at Defined Temperatures during TGA

\begin{tabular}{llllr} 
sample/temp $\left({ }^{\circ} \mathrm{C}\right)$ & 300 & 400 & 600 & 1100 \\
HA & 6.06 & 6.75 & 7.44 & 9.21 \\
Zn-HA-1 & 6.97 & 7.46 & 8.30 & 10.70 \\
Zn-HA-2 & 7.02 & 7.58 & 8.34 & 9.93 \\
Zn-MCHA & 7.74 & 8.54 & 9.38 & 13.33 \\
\hline
\end{tabular}

limit for the evaporation of entrapped $\mathrm{H}_{2} \mathrm{O}$ molecules. ${ }^{32}$ Iondoped HA powders show higher water content, particularly the multidoped Zn-MCHA. Further weight loss, up to $\sim 400{ }^{\circ} \mathrm{C}$, is ascribed to the condensation of $\mathrm{HPO}_{4}{ }^{2-}$ groups, exposed on the apatite surface, into pyrophosphate $\left(\mathrm{P}_{2} \mathrm{O}_{7}\right)$ groups ${ }^{12,15}$ Also in this case, the doped samples show higher weight loss than the undoped HA, with small differences between $\mathrm{Zn}$-HA1 and $\mathrm{Zn}-\mathrm{HA}-2$, whereas the multidoped $\mathrm{Zn}-\mathrm{MCHA}$ also shows the highest weight loss within this temperature range. The larger $\mathrm{HPO}_{4}{ }^{2-}$ content detected in the multidoped $\mathrm{Zn}$ $\mathrm{MCHA}$ can be ascribed to the enhanced population of the surface with positively charged groups such as $\mathrm{Ca}^{2+}$ ions and $\mathrm{Mg}^{2+}$ ions, both able to link $\mathrm{HPO}_{4}{ }^{2-}$, a phenomenon also observed in a previous study on the Mg-doped HA phase. ${ }^{12}$
The presence of $\mathrm{Mg}^{2+}$ ions on the $\mathrm{Zn}-\mathrm{MCHA}$ surface is also supported by the higher amount of bound water detected by TGA since $\mathrm{Mg}^{2+}$ ions are characterized by greater affinity with $\mathrm{H}_{2} \mathrm{O}$ molecules with respect to $\mathrm{Ca}^{2+} .^{33}$ Finally, TGA analysis also reports weight loss in the range of $600-1100{ }^{\circ} \mathrm{C}$ which, according to ref 27 , is related to the $\mathrm{CO}_{2}$ release provoked by the decomposition of $\mathrm{CO}_{3}{ }^{2-}$ substituting $\mathrm{PO}_{4}{ }^{3-}$ in the apatite structure (B-carbonation).

3.2. Morphological Characterization. SEM analysis of the samples reports a morphology typically characterized by rounded, slightly elongated nanoparticles (mean size: 20-50 $\mathrm{nm}$ ) clustered into micron-size agglomerates (Figure 3). The small size of the nanoparticles is consistent with the high SSA of the apatite powders, as found by the nitrogen adsorption analysis (i.e., HA: $162.34 \mathrm{~m}^{2} / \mathrm{g}$; Zn-HA-1: $170.18 \mathrm{~m}^{2} / \mathrm{g}$; ZnHA-2: $169.66 \mathrm{~m}^{2} / \mathrm{g}$; Zn-MCHA: $188.56 \mathrm{~m}^{2} / \mathrm{g}$ ). These findings are consistent with the smaller crystallite size detected in the doped apatites (Table 1).

TEM pictures of Zn-MCHA and Zn-HA-2, as representative of the single-doped $\mathrm{Zn}$-HAs, are reported in Figure 4. The morphology of the two powders slightly differs. Zn-MCHA is composed of platelike particles often agglomerated, with the major axis ranging between 50 and $75 \mathrm{~nm}$ and the minor axis between 10 and $20 \mathrm{~nm}$. Zn-HA-2 is composed of rodlike particles, with the major axis size in the $75-120 \mathrm{~nm}$ range and a much smaller minor axis ranging between 10 and $20 \mathrm{~nm}$. These results are in good agreement with the crystallite size and shape factor estimated from the XRD analysis (Table 1). The aggregation observed in the TEM picture is due to the prevalence of the electrostatic interactions of nanoparticle 

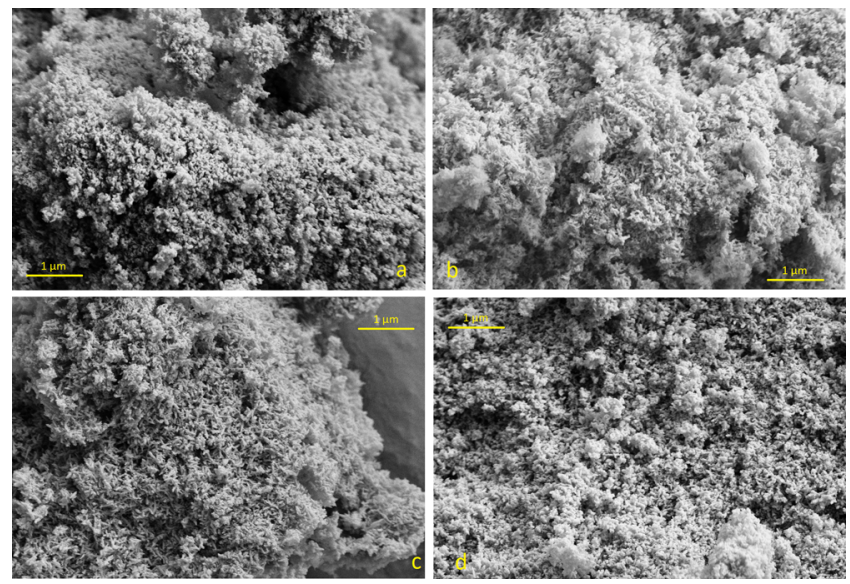

Figure 3. SEM images of (a) undoped HA, (b) Zn-HA-1, (c) Zn-HA2, and (d) Zn-MCHA powders.
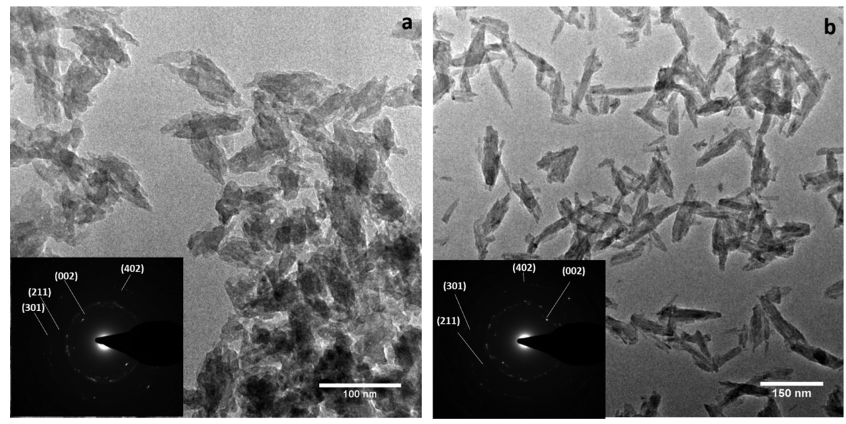

Figure 4. TEM pictures of Zn-MCHA (a) and Zn-HA-2 (b). In the insets, the relative selected area electron diffraction patterns are reported.

surface in the dry state, and hence it is not fully representative of the actual nanoparticle condition in aqueous dispersion.

STEM picture and the EDS drift-corrected spectrum profile collected on sample Zn-HA-2 are reported in Figure 5. The Ca, $\mathrm{P}$, and $\mathrm{Zn}$ profiles (Figure $5 \mathrm{~b}$ ) acquired along the yellow line highlighted in Figure 5a clearly shows the increase of the $\mathrm{Zn}$ signal in the inner part of the nanoparticle as well as the $\mathrm{Ca}$ and $\mathrm{P}$ compositions. In detail, the profiles show the compositional changes from the core to the surface of the nanoparticles, with $\mathrm{Ca}$ signals being more intense on the border and, conversely, $\mathrm{Zn}$ signals being more intense in the central part.

Figure 6 highlights that $\mathrm{Zn}-\mathrm{MCHA}$ is constituted of a crystalline core surrounded by a more disordered region, as

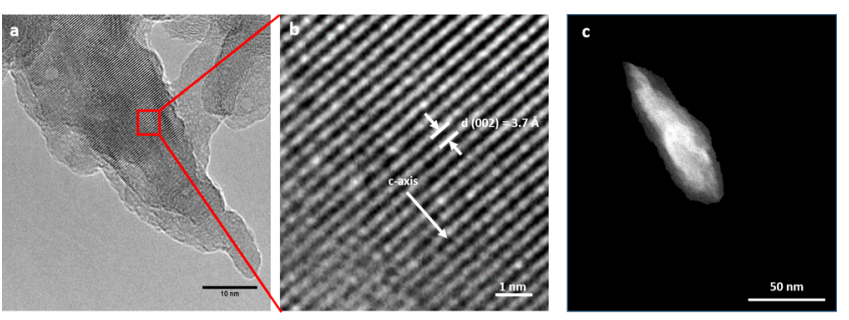

Figure 6. High-resolution TEM/STEM analysis of the Zn-MCHA nanoparticle. (a) High-resolution TEM image; (b) detail showing the apatite lattice within the particle core, with the typical interplanar distance of the [002] reflection; (c) STEM image of a single $\mathrm{Zn}$ MCHA nanoparticle.

shown by high-resolution TEM images (Figure 6a,b) and confirmed by the STEM image in Figure $6 c$, showing a lower electron dense region in the border of the nanoparticle with respect to the nanoparticle core and thus confirming the presence of less crystalline and less ordered regions on the apatite surface.

3.3. Evaluation of Ion-Exchange Profiles. The release of ions from the undoped HA, Zn-HA-1, Zn-HA-2, and ZnMCHA was investigated to obtain the biosolubility profile in the physiological environment (Hank's balanced salt solution) and to assess the ability to exchange ions when soaked in $\alpha$ MEM cell culture media. Figure 7 shows the release profile of $\mathrm{Ca}^{2+}$ and $\mathrm{Mg}^{2+}$ ions in Hank's solution, expressed in absolute values (Figure $7 \mathrm{a}$ ) and as a percentage of the initial ion content in the material (Figure $7 \mathrm{~b}$ ). No detectable release of $\mathrm{Zn}^{2+}$ ions was observed along the whole experiment; conversely, $\mathrm{Mg}^{2+}$ ions were released in a relatively large extent over time. The release of $\mathrm{Ca}^{2+}$ and $\mathrm{Mg}^{2+}$ ions can be described by two distinct mechanisms. In fact, a burst ion release was detected during the first 3 days, followed by a slower release kinetic, suggesting that within this stage, the release process involves ions
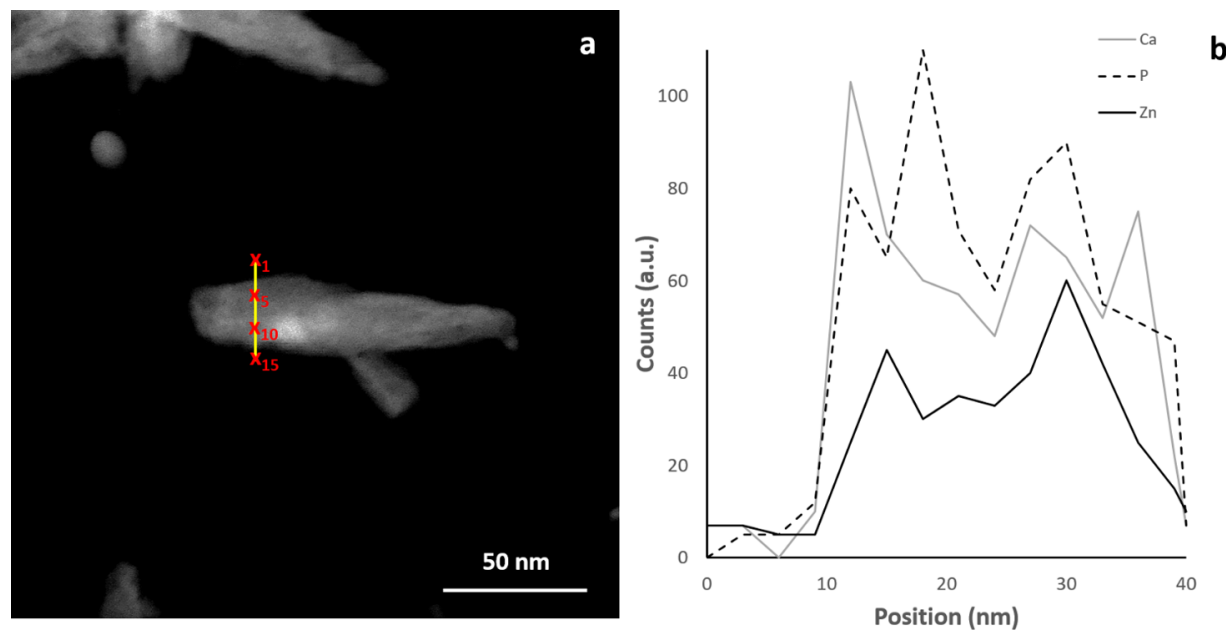

Figure 5. (a) STEM micrograph of a single Zn-HA-2 nanoparticle. (b) EDS profile taken along the yellow line having a length of $40 \mathrm{~nm}$ reported in panel (a). 

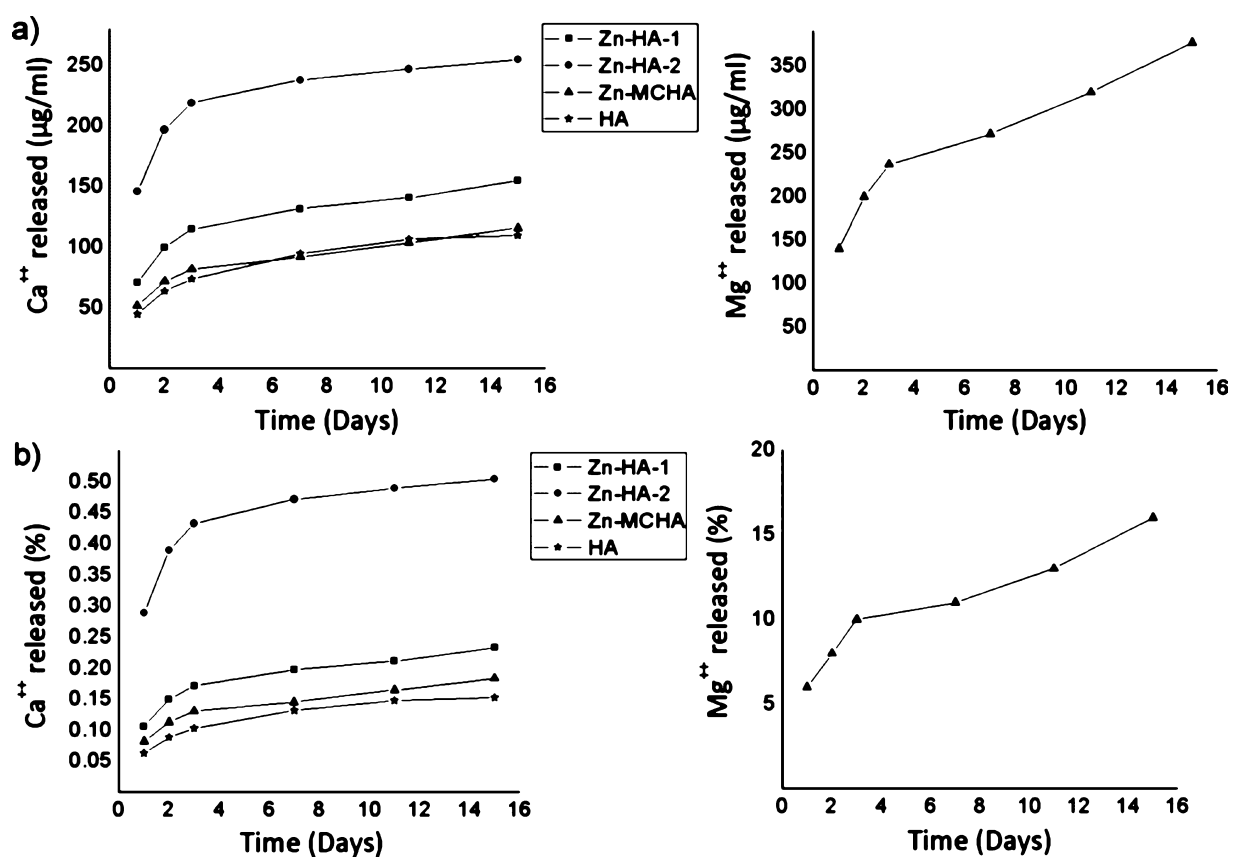

Figure 7. Ion release in physiological fluid: (a) absolute values of released ions; (b) percentage values of released ions with respect to those present in the as-obtained material. Note that no $\mathrm{Zn}$ release could be observed in any material.

characterized by relatively weaker chemical bonds. Such ions are likely located in surface regions characterized by enhanced crystal disorder, as evidenced by the STEM analysis in Figure 6. In the subsequent stage (i.e., days 3-14), the release of both $\mathrm{Ca}^{2+}$ and $\mathrm{Mg}^{2+}$ ions slackened; therefore, it can be ascribed to the dissolution of inner, more crystalline, and stable regions. Taking into account that no $\mathrm{Zn}^{2+}$ ion release was detected, we can hypothesize that $\mathrm{Zn}^{2+}$ ions do not populate such a disordered surface layer but are entirely located in the more energetically stable substitutional positions in the HA lattice. This assumption is confirmed by the TEM analysis in Figure $5 \mathrm{~b}$, showing $\mathrm{Zn}$ located prevalently in the inner regions of the $\mathrm{HA}$ structure. B-carbonated $\mathrm{Zn}-\mathrm{MCHA}$ shows ion release extent comparable with undoped HA and single-doped $\mathrm{Zn}$ HAs. This behavior is in contrast with previous studies reporting a markedly higher ion release in carbonated apatites in comparison with noncarbonated ones. ${ }^{14,27,34}$ Nevertheless, similar studies were never carried on apatites codoped with $\mathrm{Zn}^{2+}, \mathrm{Mg}^{2+}$, and $\mathrm{CO}_{3}{ }^{2-}$ ions; the unexpectedly low solubility of the carbonated $\mathrm{Zn}-\mathrm{MCHA}$ can be directly related to the phenomenon of $\mathrm{Zn}^{2+} \leftrightarrow \mathrm{Ca}^{2+}$ ion exchange in the lattice. The obtained data support the hypothesis that such substitution can sort interlinked effects as it (i) stabilizes the apatite crystal, counteracting the destabilizing effects due to substitution with $\mathrm{CO}_{3}{ }^{2}$ while at the same time it (ii) reduces the crystal size, (iii) increases the specific surface and crystal disorder on the surface, and finally (iv) promotes the release of ions from the apatitic structure.

The apatite powders were soaked into $\mathrm{Ca}$ - and $\mathrm{Mg}$-free Hank's solution, and the $\zeta$-potential was measured at prefixed timepoints (Table 4). The results show that all apatites exhibit a high negative charge, steadily decreasing with the soaking time but remaining far from electrical neutrality even after 14 days. This behavior can be ascribed to a dynamic equilibrium established on the apatite surface layer when immersed into such aqueous media, related to continuous and evolving ion mobility. In the undoped HA, the surface charge reduction is
Table 4. $\zeta$-Potential of the As-Obtained Materials vs Soaking Time

\begin{tabular}{lccccc} 
& \multicolumn{5}{c}{$\zeta$-potential $(\mathrm{mV})$} \\
\cline { 2 - 6 } sample/time & 0 & $1 \mathrm{~d}$ & $4 \mathrm{~d}$ & $7 \mathrm{~d}$ & $14 \mathrm{~d}$ \\
\cline { 2 - 6 } HA & -15.53 & -14.20 & -13.22 & -11.53 & -7.91 \\
ZnHA-1 & -17.20 & -16.37 & -15.18 & -13.60 & -13.50 \\
ZnHA-2 & -19.37 & -17.50 & -17.03 & -16.57 & -16.33 \\
Zn-MCHA & -14.60 & -13.20 & -12.76 & -12.00 & -11.03 \\
\hline
\end{tabular}

much faster than in ion-doped HAs; besides $\mathrm{Ca}^{2+}$, in the undoped HA most of the mobile ions are likely $\mathrm{HPO}_{4}{ }^{2-}$ and $\mathrm{PO}_{4}{ }^{3-}$ groups commonly present on the surface of nanocrystalline apatites. ${ }^{35}$ The negative charge of the ion-doped HAs decreases toward more negative values with the zinc content (i.e., Zn-HA-2 > Zn-HA-1 > Zn-MCHA > HA, see also Figure $7 \mathrm{~b}$ ). This finding shows that the extent of $\mathrm{Zn}^{2+}$ ion doping is related to enhanced surface activity in terms of exposed charges and improves the ability to exchange bioactive ions with aqueous media.

The surface activity of the synthesized samples was also evaluated by soaking in $\alpha \mathrm{MEM}$ cell culture medium to evaluate the ability of ion exchange in the presence of cells. Different from the test performed in ion-free Hank's balanced salt solution, the concentration of $\mathrm{Ca}^{2+}$ and $\mathrm{Mg}^{2+}$ ions in $\alpha \mathrm{MEM}$ pushes ion absorption rather than release (Figure 8 ). The tests show continuous absorption of $\mathrm{Ca}^{2+}$ and $\mathrm{Mg}^{2+}$ ions already present in the fluid, particularly within the first 3 days; later, the absorption process reaches a saturation level and is described by a plateau. $\mathrm{Ca}^{2+}$ ions are absorbed in a similar extent by the three tested apatite powders (Figure 8a). The extent of $\mathrm{Ca}^{2+}$ ion adsorption in percentage follows the trend of $\mathrm{Ca}^{2+}$ release detected in the experiments carried out in Hank's balanced salt solution (i.e., Zn-HA-1 > Zn-MCHA > HA, see Figure $7 b$ ). This confirms the correlation between the ion mobility in the apatites and the extent of $\mathrm{Zn} \leftrightarrow \mathrm{Ca}$ exchange in the lattice. The absorption of $\mathrm{Mg}^{2+}$ ions is 

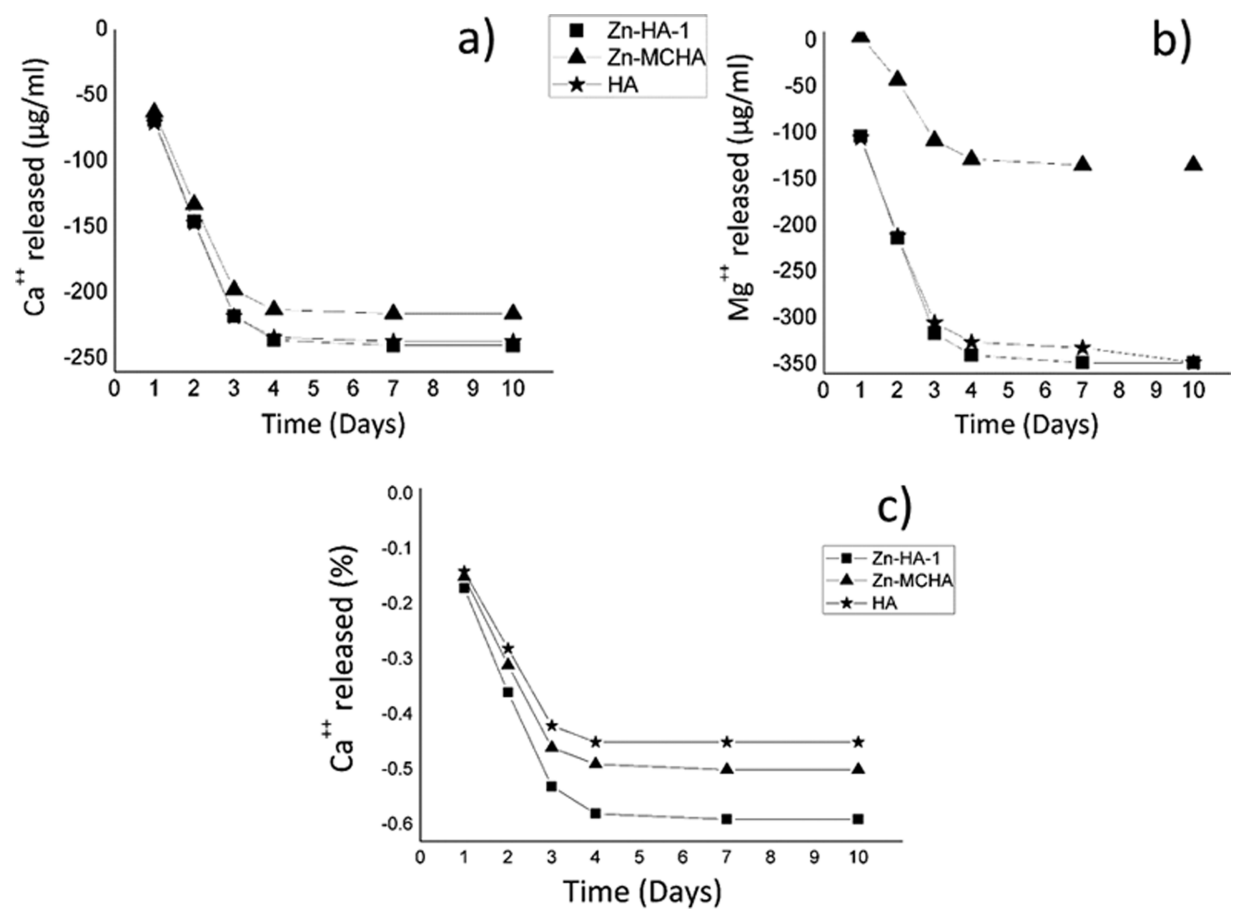

Figure 8. Ion-exchange profile evaluated in $\alpha \mathrm{MEM}$ cell culture medium.

$50 \mu \mathrm{g} / \mathrm{ml}$

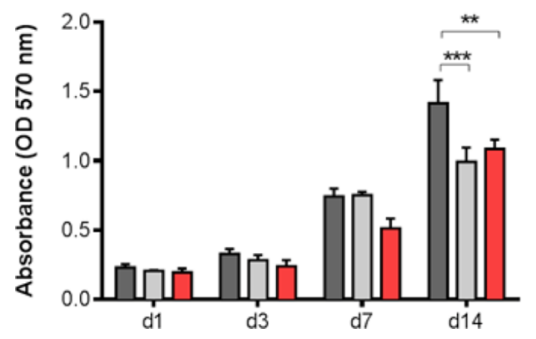

$500 \mu \mathrm{g} / \mathrm{ml}$

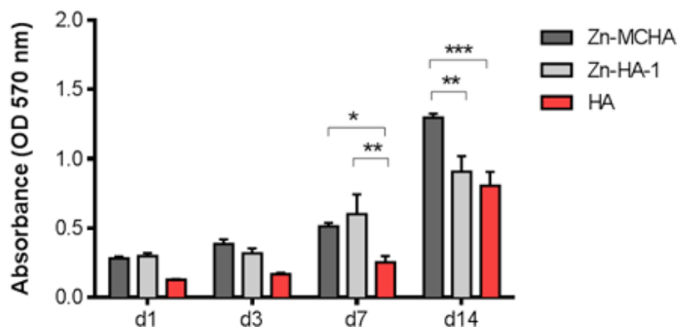

Figure 9. Analysis of cell proliferation by the MTT assay after 1,3, 7, and 14 days of ASCs seeded with 50 and $500 \mu \mathrm{g} / \mathrm{mL}$ of the samples. *p $\leq$ $0.05 ; * p \leq 0.01$, and $* * * p \leq 0.001 . n=3$.
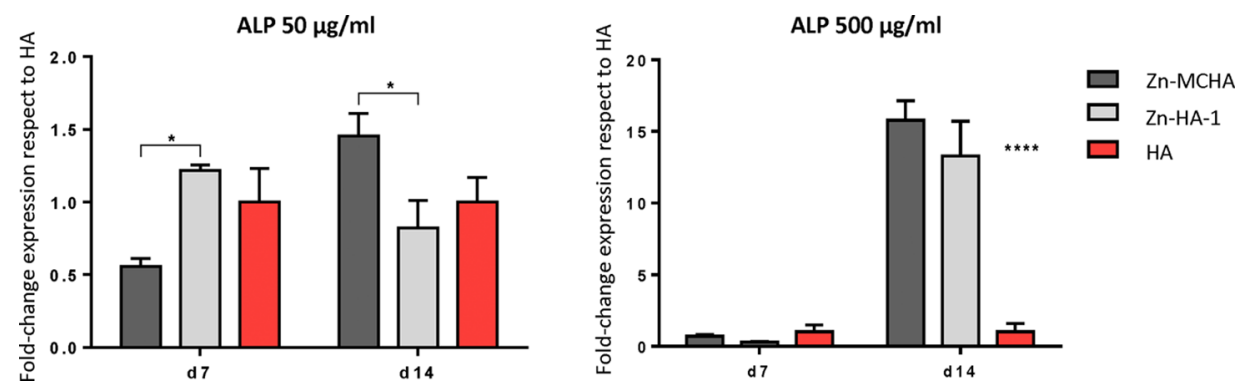

Figure 10. Relative quantification $\left(2^{-\Delta \Delta C_{t}}\right)$ of ALP expression after 7 and 14 days of ASCs cultured in contact with all samples. The graphs report the mean and standard error of the technical triplicate of ALP with respect to the expression of cells in contact with HA, used as the control. (* $p \leq$ $0.05 ; * * * p \leq 0.001 ; * * * * \leq 0.0001)$.

observed in all of the apatites but less evident in the multidoped Zn-MCHA, thus suggesting that Zn-MCHA already exposes a significant fraction of $\mathrm{Mg}^{2+}$ charges on the surface (Figure $8 \mathrm{~b}$ ). The ability of the studied apatites to expose $\mathrm{Mg}^{2+}$ ions permit to greatly increase their affinity with cells and enhance bioactivity. ${ }^{33,36}$

3.4. Biological Characterization. In vitro analysis with human adipose stem cells (ASCs) was carried out on three selected materials: Zn-HA-1, Zn-MCHA, and the undoped HA chosen as the reference. The ASC behavior in contact with two different concentrations of powders was investigated in vitro looking at the cell viability, cell morphology, and expression of ALP osteogenic-related gene and COL-1 and Runx2 protein evaluation up to 14 days of culture. The quantification of metabolically active cells shows a significant enhancement in cell proliferation induced by the presence of $\mathrm{Zn}$ and $\mathrm{Mg}$. The effect induced by $\mathrm{Zn}$ seems to be dose-dependent; in fact, a significant difference was observed after 7 days of culture in the 
presence of $500 \mu \mathrm{g} / \mathrm{mL}$, whereas in the presence of $50 \mu \mathrm{g} / \mathrm{mL}$, the induction of proliferation is evident on day 14 and it seems related to the presence of $\mathrm{Mg}$ (Figure 9). This confirms the direct effect of $\mathrm{Zn}^{2+}$ doping to enhance the surface activity of the HAs that this test showed to be beneficial for stem cell proliferation. The effect of $\mathrm{Mg}^{2+}$ ions exposure is also evidenced by the increased stem cell proliferation in $\mathrm{Zn}$ $\mathrm{MCHA}$ at any dose, particularly effective in the long term.

In order to assess any osteoinductive effects of the new phases on ASC differentiation, gene expression analysis of ALP was evaluated by quantitative polymerase chain reaction (Figure 10), and RUNX2 and COL-1 proteins were qualitatively detected by the immunofluorescent analysis (Figure 11). All osteogenic markers appear to be upregulated
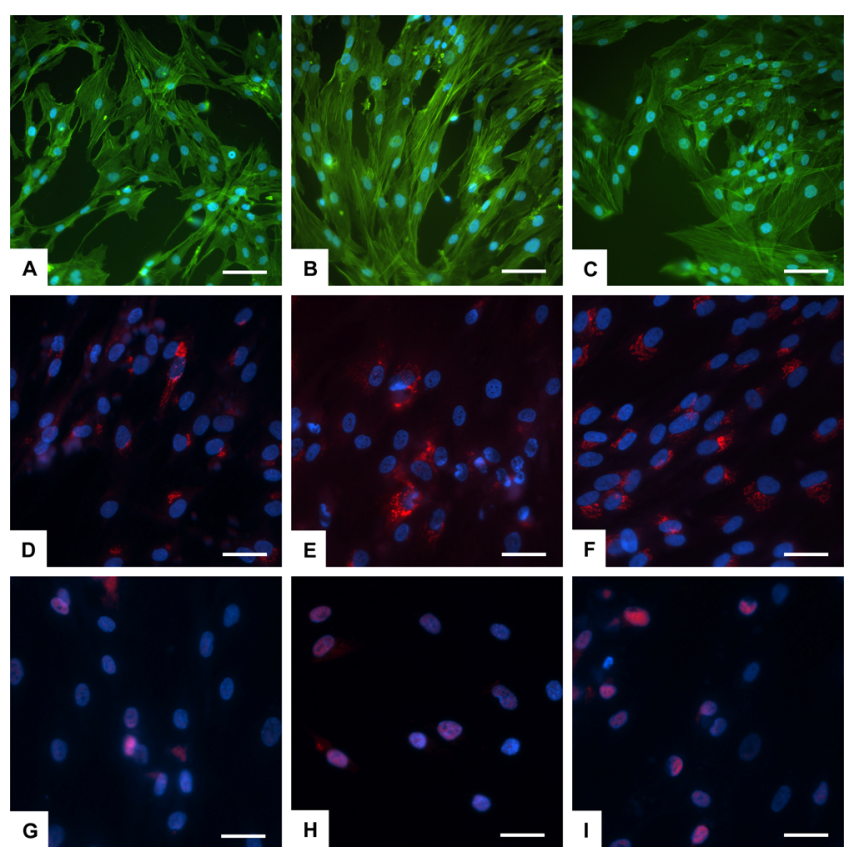

Figure 11. Analysis of cell morphology on day 3 seeded with the highest concentration of samples (A-C). Phalloidin in green stains for actin filaments and DAPI in blue stains for cell nuclei. Immunofluorescent analysis of COL-1 (D-F) on day $7(500 \mu \mathrm{g} /$ $\mathrm{mL}$ ). Staining of COL-1 (in red) and cell nuclei (in blue). Immunofluorescent analysis of RUNX2 (G-I) on day $7(500 \mu \mathrm{g} /$ $\mathrm{mL})$. Staining of RUNX2 (in red) and cell nuclei (in blue). (A,D,G) HA group. (B,E,H) Zn-HA. (C,F,I) Zn-MCHA. Scale bars: (A-C) 80 $\mu \mathrm{m}$; (D-I) $50 \mu \mathrm{m}$.

in the cells cultured with $500 \mu \mathrm{g} / \mathrm{mL}$ of both $\mathrm{Zn}-\mathrm{HA}-1$ and $\mathrm{Zn}$ MCHA, indicating that the doping with $\mathrm{Zn}^{2+}$ acts as an osteoinductive factor, whereas the exposure of $\mathrm{Mg}^{2+}$ ions further strengthens the osteo-differentiative ability, particularly if present in relevant doses. These findings suggest that codoping with $\mathrm{Zn}^{2+}$ and $\mathrm{Mg}^{2+}$ can greatly enhance the ability of HA to sustain stem cell proliferation and appropriate differentiation for an extended time lapse and thus promote new bone tissue formation.

3.5. Antimicrobial Test. The antimicrobial effect of the ion-doped Zn-HA-1, Zn-HA-2, and Zn-MCHA materials, in comparison with undoped HA, was tested with four different bacterial strains: P. aeruginosa, E. coli, S. aureus, that is, two Gram- and one Gram+ bacteria, respectively, and a yeast, $C$. albicans. In order to evaluate the effect of ions released or exposed on the apatite surface, when soaked in the culture medium, the antimicrobial tests were carried out on two different sets of materials: the first set (coded as PRISTINE) was used as obtained; the second set (coded as AGED) was used after aging into $\mathrm{pH} 7.4$ buffer solution (Ca- and $\mathrm{Mg}$-free Hank's balanced salt solution) for 14 days, that is, under the same experimental conditions and timing adopted with the ion-release test described in Figure 7, to test the bioactivity of the apatites after elimination of a significant extent of labile ions from the apatite surface and subsurface regions.

PRISTINE samples exhibit remarkable ability of bacterial inhibition after $24 \mathrm{~h}$ (Figure 12), particularly, more rapid and enhanced antibacterial activity is shown by the multidoped $\mathrm{Zn}$ MCHA (99.999\% of bacterial reduction) with respect to the control undoped HA, which shows the lowest effectiveness at all of the investigated timepoints and the lowest antiproliferative ability after $24 \mathrm{~h}$ for all of the considered infective strains. Figure 13 shows that the AGED Zn-MCHA retains relevant ability of microbial inhibition at a level similar to the PRISTINE material. The remaining materials of the AGED group shows marked reduction of their antibacterial activity compared with the PRISTINE group, particularly for S. aureus and E. coli. Remarkably, single-doped Zn-HA materials (both Zn-HA-1 and Zn-HA-2) show high effectiveness against the yeast $C$. albicans. These results suggest that the doping with $\mathrm{Zn}^{2+}$ ions is relevant to confer enhanced antibacterial ability to $\mathrm{HA}$; however, it appears that $\mathrm{Mg}^{2+}$ ions-exposed at the surface or exchanged-are able to further enhance antibacterial ability and effectiveness over a wider spectrum of infective strains.

\section{DISCUSSION}

The present study shows that the investigated ion-doped HAs have excellent osteoinductive properties and, at the same time, enhanced inhibitory abilities against various pathogens selected among the most frequent responsible for nosocomial infections. The key factor at the basis of enhanced biofunctionalities of multidoped $\mathrm{HA}$ is the increased lattice disorder induced by the $\mathrm{Zn} \leftrightarrow \mathrm{Ca}$ exchange within the apatite lattice and the consequent increase of the surface charge and ability of prolonged exchange of bioactive ions such as $\mathrm{Ca}^{2+}$, $\mathrm{Mg}^{2+}$, and $\mathrm{HPO}_{4}{ }^{2-}$, which are known as biospecific chemical signals active in bone regeneration.

Physicochemical mechanisms related to enhanced osteogenic and antimicrobial properties can be related to the location of the doping ions into the structure of nanocrystalline HAs and, consequently, to their mobility. During the formation of the apatite phase by the wet neutralization method, $\mathrm{Zn}^{2+}$ ions occupy substitutional positions at calcium lattice sites. This provokes the segregation of $\mathrm{Ca}^{2+}$ ions at surface regions characterized by low-range crystal order and weaker chemical bonds, thus enhancing the ability of ion exchange in aqueous media. In HA samples doped with only $\mathrm{Zn}^{2+}$ ions, the exchange process involves only $\mathrm{Ca}^{2+}$ ions, as $\mathrm{Zn}^{2+}$ ions occupy stable crystal sites and are not released in any amounts even after 14 days of soaking in a physiological medium. Conversely, considering the sustained release profile of $\mathrm{Mg}^{2+}$ ions, we can suppose that they are relatively weakly bound to the apatite structure and thus, in combination with $\mathrm{Ca}^{2+}$, they could be involved in a continuous ion-exchange process, functioning as bioactive chemical signals for human cells and bacteria.

With stem cells, such signals greatly improve the viability, proliferation, and osteogenic character, particularly for the multidoped Zn-MCHA phase. The adoption of bodylike 

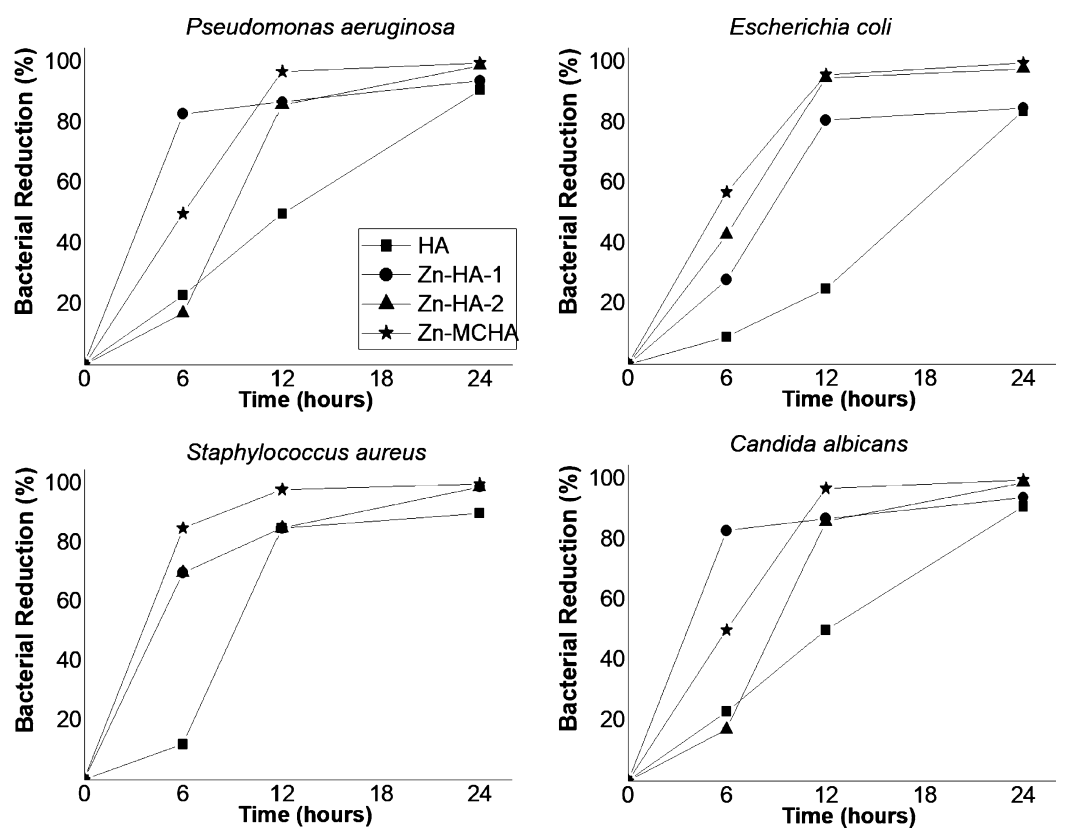

Figure 12. Microbial reduction for all infective strains in the PRISTINE materials.
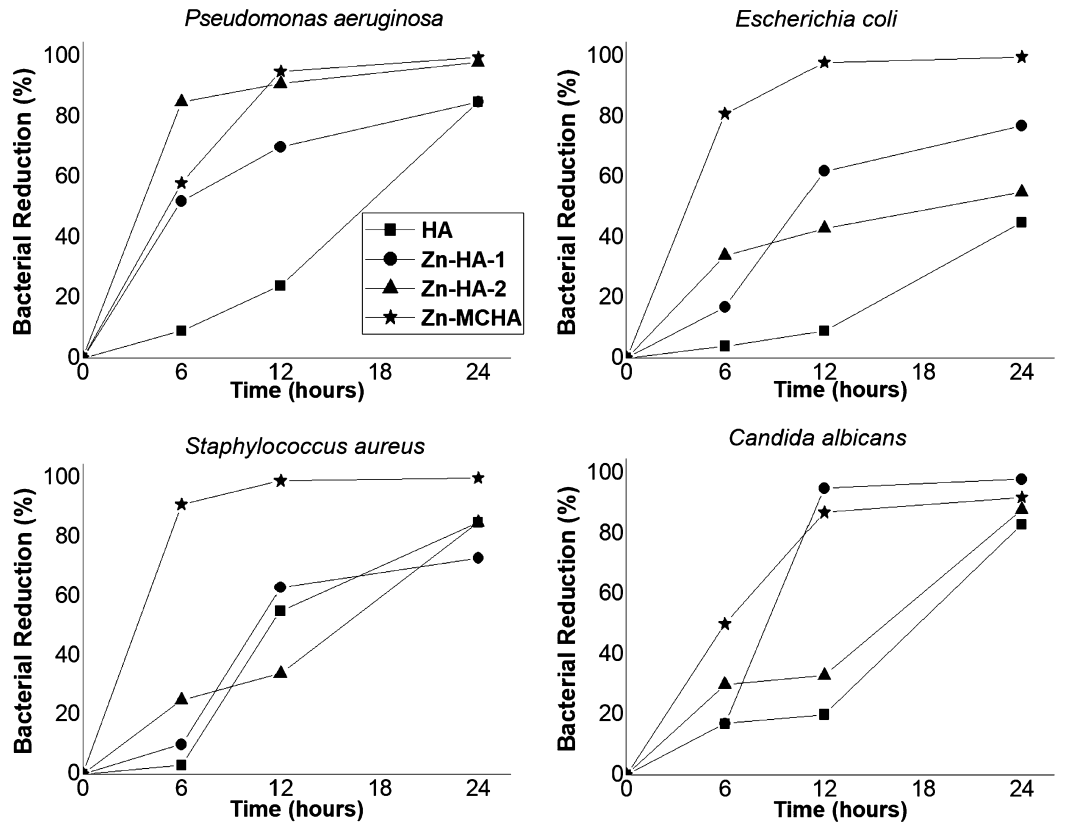

Figure 13. Microbial reduction for all infective strains in the AGED materials.

temperature conditions for HA synthesis allowed to obtain a nanocrystalline mineral phase with physicochemical properties, mimicking the biologic apatite present in the immature bone tissue. B-type carbonation, the presence and exchange of doping $\mathrm{Mg}^{2+}$ ions, reduced hydroxylation extent, and very small crystal size are all features previously reported as triggers for new bone formation. ${ }^{13,37-40}$ Our result indicates that the use of biomaterials combining all these features is promising to significantly enhance the bone-forming ability of human stem cells, as demonstrated by the upregulation of specific osteogenic markers (i.e., ALP, RUNX2, and COL1). It is well known, in fact, that the presence of ALP and RUNX2 activity is explicitly required to trigger the initial osteogenic regulatory network and direct the bone developmental program, while the production of COL-1 confirms the differentiation into osteogenic lineage of ASCs. ${ }^{4-43}$

Regarding the effect on pathogens, previous studies investigated $\mathrm{Zn}$-doped $\mathrm{HA}$ as an antibacterial material. In fact, $\mathrm{Zn}^{2+}$ can interact with bacterial cytoplasm and proteins, thus inhibiting the uptake of metal ions relevant for bacterial metabolism such as $\mathrm{Mn}^{2+} \cdot{ }^{44}$ Furthermore, $\mathrm{Zn}^{2+}$ ions can easily bind to the negatively charged bacterial membrane and prevent bacterial adhesion and biofilm formation. ${ }^{45,46}$ However, our results show that $\mathrm{Zn}^{2+}$ ions are not released in any extent but, on the other hand, they enhanced the release of divalent ions such as $\mathrm{Ca}^{2+}$ and $\mathrm{Mg}^{2+}$. Thus, we can hypothesize that the release of ions such as $\mathrm{Ca}^{2+}$ and $\mathrm{Mg}^{2+}$ could be effective in inhibiting bacterial viability by activation of similar mechanisms as those observed by Couñago et al. who tested $\mathrm{Zn}^{2+}$ 
ions directly introduced in the bacterial culture. ${ }^{44}$ In fact, the antimicrobial ability is significantly enhanced in the multidoped Zn-MCHA powder in comparison with single-doped Zn-HA-1, since complete eradication of all tested infective strains was achieved within only $12 \mathrm{~h}$. Remarkably, Zn-MCHA shows excellent behavior even when tested in its AGED form (Figure 13), confirming its ability to reduce the majority of potentially pathogenic bacteria by $99.999 \%$ within $12 \mathrm{~h}$, with particular respect to the Gram-negative E. coli and the Grampositive $S$. aureus strains, against which $\mathrm{Zn}-\mathrm{MCHA}$ shows much higher effectiveness than the other tested materials. This latter case is significant, as $\mathrm{HA}$ was previously reported as ineffective against various Gram-positive bacteria including $S$. aureus. ${ }^{7}$ However, in that previous study, the HA used for the test was well crystalline, in consequence of its synthesis carried out at $60-80^{\circ} \mathrm{C}$. In the same study, amorphous CaPs, a highly bioactive material characterized by very low crystallinity, reported instead good effectiveness also against Gram+ bacteria.

It can be devised, therefore, that low crystallinity extent and high ion mobility are key features to exhibit enhanced biofunctionality, particularly, we observed excellent eukaryotic versus prokaryotic cell selectivity related to improved osteogenic and antimicrobial ability, particularly in the multidoped Zn-MCHA. Such a condition was obtained, thanks to the use of a low synthesis temperature and multiple-ion doping, through which it was possible to tailor relevant physicochemical features such as (i) high SSA and charge; (ii) high mobility of bioactive ions from the apatite surface and subsurface; and (iii) type and amount of doping ions. Besides providing good affinity with stem cell polarity, the high surface charge can provide bioelectric effect contrasting bacterial biofilm formation. ${ }^{47}$ This could be particularly effective in the ion-doped apatites, which show higher surface charge. The design of nanocrystalline apatites permitting the exchange of foreign divalent ions having specific biologic functions can bring to a variety of devices intended for specific applications in medicine. For instance, the doping with $\mathrm{Mg}^{2+}$ and/or $\mathrm{Sr}^{2+}$ can yield anti-osteoporotic effect ${ }^{48-50}$ while preventing, at the same time, secondary complications such as infections that are a primary cause of failure of implanted devices. In particular, the long lasting bioactivity and multifunctional ability shown by $\mathrm{Zn}$-MCHA make it very promising for frontier applications in medicine, to provide sustained therapeutic and protective effects in the case of bone reconstruction/regeneration procedures, or as a coating for metal-based implants to enhance osteointegration and primary fixation with a significant cut of postoperatory infective phenomena.

Despite several studies carried out to date, a substantial agreement has not yet been found in defining which physicochemical features a biomaterial should exhibit to ensure effective advantages to prevent infections and biofilm formation. ${ }^{51,52}$ In this respect, the present work highlights that nanomaterials with a highly active surface such as ion-doped nanocrystalline apatites can exert substantial antimicrobial effect by aid of inherent molecular mechanisms mediated by divalent ions, which also result in enhanced safety for stem cells and in increased regenerative potential. Such molecular mechanisms can act on a wider range of targets than narrowspectrum antibiotics, and therefore, the use of multidoped apatites can be effective in the prevention of bacterial infections over a broad spectrum and also useful to overcome multidrug resistance now typical of many micro-organisms. ${ }^{53}$
This hypothesis requires further studies and dedicated in vivo trials to confirm the enhanced multifunctional ability of multidoped biomimetic apatites in real clinical cases. Success in this respect may open a new class of biomaterials able to solve crucial and impellent medical needs and-not negligible-with marketability facilitated by easy translational processes (i.e., the product is a purely inorganic HA) and with perspective of wide applications in many different fields, where microbial-free surfaces are needed.

\section{CONCLUSIONS}

The ever raising occurrence of nosocomial infections and related diseases is pushing material scientists to develop new therapeutic biomaterials capable of effective and durable protection against bacterial proliferation and biofilm formation. In this paper, multidoped nanocrystalline HA shows very promising features for primary versus pathogenic cell selectivity, as attested by effective cell-instructing and longterm antimicrobial abilities. Relevant physicochemical mechanisms at the base of such unique properties are related to nanocrystallinity, high SSA and surface charge, and triggering of ion-exchange phenomena (particularly, $\mathrm{Mg}^{2+}$ ) exerting stimuli on stem cells and pathogens. These features were obtained thanks to the incorporation of multiple doping ions; specifically, the doping with $\mathrm{Zn}^{2+}$ induced the segregation of bioactive ions on the material surface making them available for exchange with physiological fluids, promising to be effective to sustain bone regeneration with reduced complications in the postoperative period. Particularly, since a marked anti-infective ability was obtained without using any antibiotic drugs, this is promising to prevent bacterial antibiotic resistance in hospitals, which is becoming a pandemic problem. Therefore, biomimetic materials such as multidoped HA phases are relevant candidates for the development of a new generation of medical devices with improved therapeutic effectiveness and for solving crucial and still unmet clinical needs.

\section{AUTHOR INFORMATION}

\section{Corresponding Author}

*E-mail: simone.sprio@istec.cnr.it. Phone: +390546 699759. Fax: +390546 46381 .

\section{ORCID}

Simone Sprio: 0000-0003-1526-7915

Alessio Adamiano: 0000-0002-2077-0411

Nicola M. Pugno: 0000-0003-2136-2396

\section{Notes}

The authors declare no competing financial interest.

\section{ACKNOWLEDGMENTS}

The authors wish to acknowledge Dr. A. Ballardini for his support in material synthesis and A. Piancastelli for the execution of the SSA measurements. N.M.P. is supported by the European Commission under the Graphene Flagship Core 2 grant no. 785219 (WP14 'Composites') and FET Proactive 'Neurofibres' grant no. 732344, as well as by the Italian Ministry of Education, University and Research (MIUR) under the 'Departments of Excellence' grant L. 232/2016 and AR 901-01384-PROSCAN and PRIN-20177TTP3S. 


\section{REFERENCES}

(1) Li, B.; Webster, T. J. Bacteria antibiotic resistance: New challenges and opportunities for implant-associated orthopedic infections. J. Orthop. Res. 2018, 36, 22-32.

(2) Hofer, U. The cost of antimicrobial resistance. Nat. Rev. Microbiol. 2019, 17, 3.

(3) Slavin, Y. N.; Asnis, J.; Häfeli, U. O.; Bach, H. Metal nanoparticles: understanding the mechanisms behind antibacterial activity. J. Nanobiotechnol. 2017, 15, 1-20.

(4) Gliga, A. R.; Skoglund, S.; Odnevall Wallinder, I.; Fadeel, B.; Karlsson, H. L. Size-dependent cytotoxicity of silver nanoparticles in human lung cells: the role of cellular uptake, agglomeration and $\mathrm{Ag}$ release. Part. Fibre Toxicol. 2014, 11, 11.

(5) Albers, C. E.; Hofstetter, W.; Siebenrock, K. A.; Landmann, R.; Klenke, F. M. In vitrocytotoxicity of silver nanoparticles on osteoblasts and osteoclasts at antibacterial concentrations. Nanotoxicology 2013, 7, 30-36.

(6) Vimbela, G.; Ngo, S. M.; Fraze, C.; Yang, L.; Stout, D. A. Antibacterial properties and toxicity from metallic nanomaterials. Int. J. Nanomed. 2017, 12, 3941-3965.

(7) Wu, V. M.; Tang, S.; Uskoković, V. Calcium Phosphate Nanoparticles as Intrinsic Inorganic Antimicrobials: The Antibacterial Effect. ACS Appl. Mater. Interfaces 2018, 10, 34013-34028.

(8) Thian, E. S.; Konishi, T.; Kawanobe, Y.; Lim, P. N.; Choong, C.; Ho, B.; Aizawa, M. Zinc-substituted hydroxyapatite: a biomaterial with enhanced bioactivity and antibacterial properties. J. Mater. Sci.: Mater. Med. 2013, 24, 437-445.

(9) Stanić, V.; Dimitrijević, S.; Antić-Stanković, J.; Mitrić, M.; Jokić, B.; Plećas, I. B.; Raičević, S. Synthesis, characterization and antimicrobial activity of copper and zinc-doped hydroxyapatite nanopowders. Appl. Surf. Sci. 2010, 256, 6083-6089.

(10) Tampieri, A.; Ruffini, A.; Ballardini, A.; Montesi, M.; Panseri, S.; Salamanna, F.; Fini, M.; Sprio, S. Heterogeneous chemistry in the 3-D state: an original approach to generate bioactive, mechanicallycompetent bone scaffolds. Biomater. Sci. 2018, 7, 307-321.

(11) Tapiero, H.; Tew, K. D. Trace elements in human physiology and pathology: zinc and metallothioneins. Biomed. Pharmacother. 2003, 57, 399-411.

(12) Landi, E.; Logroscino, G.; Proietti, L.; Tampieri, A.; Sandri, M.; Sprio, S. Biomimetic Mg-substituted hydroxyapatite: from synthesis to in vivo behaviour. J. Mater. Sci.: Mater. Med. 2008, 19, 239-247.

(13) Bigi, A.; Foresti, E.; Gregorini, R.; Ripamonti, A.; Roveri, N.; Shah, J. S. The role of magnesium on the structure of biological apatites. Calcif. Tissue Int. 1992, 50, 439-444.

(14) Sprio, S.; Tampieri, A.; Landi, E.; Sandri, M.; Martorana, S.; Celotti, G.; Logroscino, G. Physico-chemical properties and solubility behaviour of multi-substituted hydroxyapatite powders containing silicon. Mater. Sci. Eng., C 2008, 28, 179-187.

(15) Landi, E.; Tampieri, A.; Mattioli-Belmonte, M.; Celotti, G.; Sandri, M.; Gigante, A.; Fava, P.; Biagini, G. Biomimetic Mgsubstituted hydroxyapatite: from synthesis to in vivo behavior. J. Eur. Ceram. Soc. 2006, 26, 2593-2601.

(16) Ballardini, A.; Montesi, M.; Panseri, S.; Vandini, A.; Balboni, P. G.; Tampieri, A.; Sprio, S. New hydroxyapatite nanophases with enhanced osteogenic and anti-bacterial activity. J. Biomed. Mater. Res., Part A 2018, 106, 521-530.

(17) Combes, C.; Cazalbou, S.; Rey, C. Apatite Biominerals. Minerals 2016, 6, 34.

(18) Yamaguchi, M. Role of Zinc in Bone Metabolism and Preventive Effect on Bone Disorder. Biomed. Res. Trace Elem. 2007, $18,346-366$

(19) Plum, L. M.; Rink, L.; Haase, H. The essential toxin: impact of zinc on human health. Int. J. Environ. Res. Public Health 2010, 7, $1342-1365$.

(20) Miyaji, F.; Kono, Y.; Suyama, Y. Formation and structure of zinc-substituted calcium hydroxyapatite. Mater. Res. Bull. 2005, 40, 209-220.
(21) Ren, F.; Xin, R.; Ge, X.; Leng, Y. Characterization and structural analysis of zinc-substituted hydroxyapatites. Acta Biomater. 2009, 5, 3141-3149.

(22) Sauer, K.; Camper, A. K.; Ehrlich, G. D.; Costerton, J. W.; Davies, D. G. Pseudomonas aeruginosa displays multiple phenotypes during development as a biofilm. J. Bacteriol. 2002, 184, 1140-1154.

(23) Pammi, M.; Liang, R.; Hicks, J.; Mistretta, T.-A.; Versalovic, J. Biofilm extracellular DNA enhances mixed species biofilms of Staphylococcus epidermidis and Candida albicans. BMC Microbiol. 2013, 13, 257.

(24) Campoccia, D.; Montanaro, L.; Arciola, C. R. The significance of infection related to orthopedic devices and issues of antibiotic resistance. Biomaterials 2006, 27, 2331-2339.

(25) Zajonz, D.; Zieme, A.; Prietzel, T.; Moche, M.; Tiepoldt, S.; Roth, A.; Josten, C.; von Salis-Soglio, G. F.; Heyde, C. E.; Ghanem, M. Periprosthetic joint infections in modular endoprostheses of the lower extremities: a retrospective observational study in 101 patients. Patient Saf. Surg. 2016, 10, 6.

(26) Wall, D. Kin Recognition in Bacteria. Annu. Rev. Microbiol. 2016, 70, 143-160.

(27) Landi, E.; Sprio, S.; Sandri, M.; Celotti, G.; Tampieri, A. Development of $\mathrm{Sr}$ and $\mathrm{CO} 3$ co-substituted hydroxyapatites for biomedical applications. Acta Biomater. 2008, 4, 656-663.

(28) Li, M. O.; Xiao, X.; Liu, R.; Chen, C.; Huang, L. Structural characterization of zinc-substituted hydroxyapatite prepared by hydrothermal method. J. Mater. Sci.: Mater. Med. 2008, 19, 797-803.

(29) Hayakawa, S.; Ando, K.; Tsuru, K.; Osaka, A.; Fujii, E.; Kawabata, K.; Bonhomme, C.; Babonneau, F. Structural characterization and protein adsorption property of hydroxyapatite particles modified with zinc ions. J. Am. Ceram. Soc. 2007, 90, 565-569.

(30) Turunen, M. J.; Kaspersen, J. D.; Olsson, U.; Guizar-Sicairos, M.; Bech, M.; Schaff, F.; Tägil, M.; Jurvelin, J. S.; Isaksson, H. Bone mineral crystal size and organization vary across mature rat bone cortex. J. Struct. Biol. 2016, 195, 337-344.

(31) Boivin, G. The hydroxyapatite crystal, a closer look. Medicographia 2007, 29, 26-132.

(32) Sakhno, Y.; Bertinetti, L.; Iafisco, M.; Tampieri, A.; Roveri, N.; Martra, G. Surface Hydration and Cationic Sites of Nanohydroxyapatites with Amorphous or Crystalline Surfaces: A Comparative Study. J. Phys. Chem. C 2010, 114, 16640-16648.

(33) Bertinetti, L.; Drouet, C.; Combes, C.; Rey, C.; Tampieri, A.; Coluccia, S.; Martra, G. Surface characteristics of nanocrystalline apatites: effect of $\mathrm{mg}$ surface enrichment on morphology, surface hydration species, and cationic environments. Langmuir 2009, 25, $5647-5654$

(34) Jahnke, R. A. The synthesis and solubility of carbonate fluorapatite. Am. J. Sci. 1984, 284, 58-78.

(35) Rey, C.; Shimizu, M.; Collins, B.; Glimcher, M. J. Resolutionenhanced Fourier transform infrared spectroscopy study of the environment of phosphate ions in the early deposits of a solid phase of calcium-phosphate in bone and enamel, and their evolution with age. I: Investigations in the upsilon $4 \mathrm{PO} 4$ domain. Calcif. Tissue Int. 1990, 46, 384-394.

(36) Cazalbou, S.; Eichert, D.; Ranz, X.; Drouet, C.; Combes, C.; Harmand, M. F.; Rey, C. Ion exchanges in apatites for biomedical application. J. Mater. Sci.: Mater. Med. 2005, 16, 405-409.

(37) Roy, M.; Bose, S. Osteoclastogenesis and osteoclastic resorption of tricalcium phosphate: effect of strontium and magnesium doping. J. Biomed. Mater. Res., Part A 2012, 100, 24502461.

(38) Rey, C.; Miquel, J. L.; Facchini, L.; Legrand, A. P.; Glimcher, M. J. Hydroxyl groups in bone mineral. Bone 1995, 16, 583-586.

(39) Pasteris, J. D.; Wopenka, B.; Freeman, J. J.; Rogers, K.; ValsamiJones, E.; van der Houwen, J. A. M.; Silva, M. J. Lack of $\mathrm{OH}$ in nanocrystalline apatite as a function of degree of atomic order: implications for bone and biomaterials. Biomaterials 2004, 25, 229238. 
(40) Cazalbou, S.; Combes, C.; Eichert, D.; Rey, C.; Glimcher, M. J. Poorly crystalline apatites: evolution and maturation in vitro and in vivo. J. Bone Miner. Metab. 2004, 22, 310-317.

(41) Thiagarajan, L.; Abu-Awwad, H. A.-D. M.; Dixon, J. E. Osteogenic Programming of Human Mesenchymal Stem Cells with Highly Efficient Intracellular Delivery of RUNX2. Stem Cells Transl. Med. 2017, 6, 2146-2159.

(42) Wu, L.; Wu, Y.; Lin, Y.; Jing, W.; Nie, X.; Qiao, J.; Liu, L.; Tang, W.; Tian, W. Osteogenic differentiation of adipose derived stem cells promoted by overexpression of osterix. Mol. Cell. Biochem. 2007, 301, 83-92.

(43) Andrade, G. F.; Carvalho, J. L.; Júnior, A. S. C.; Goes, A. M.; Sousa, E. M. B. Osteogenic differentiation of adipose-derived stem cells in mesoporous SBA-16 and SBA-16 hydroxyapatite scaffolds.

RSC Adv. 2015, 5, 54551-54562.

(44) Couñago, R. M.; Ween, M. P.; Begg, S. L.; Bajaj, M.; Zuegg, J.; O’Mara, M. L.; Cooper, M. A.; McEwan, A. G.; Paton, J. C.; Kobe, B.; McDevitt, C. A. Imperfect coordination chemistry facilitates metal ion release in the Psa permease. Nat. Chem. Biol. 2014, 10, 35-41.

(45) Wu, C.; Labrie, J.; Tremblay, Y. D. N.; Haine, D.; Mourez, M.; Jacques, M. Zinc as an agent for the prevention of biofilm formation by pathogenic bacteria. J. Appl. Microbiol. 2013, 115, 30-40.

(46) Brown, L. R.; Caulkins, R. C.; Schartel, T. E.; Rosch, J. W.; Honsa, E. S.; Schultz-Cherry, S.; Meliopoulos, V. A.; Cherry, S.; Thornton, J. A. Increased Zinc Availability Enhances Initial Aggregation and Biofilm Formation of Streptococcus pneumoniae. Front. Cell. Infect. Microbiol. 2017, 7, 233.

(47) Del Pozo, J. L.; Rouse, M. S.; Patel, R. Bioelectric effect and bacterial biofilms. A systematic review. Int. J. Artif. Organs 2008, 31, 786-795.

(48) Galli, S. The effect of magnesium on early osseointegration in osteoporotic bone: a histological and gene expression investigation: response to comments by Marcus. Osteoporosis Int. 2018, 29, 10051006.

(49) Saidak, Z.; Marie, P. J. Strontium signaling: molecular mechanisms and therapeutic implications in osteoporosis. Pharmacol. Ther. 2012, 136, 216-226.

(50) Iafisco, M.; Ruffini, A.; Adamiano, A.; Sprio, S.; Tampieri, A. Biomimetic magnesium-carbonate-apatite nanocrystals endowed with strontium ions as anti-osteoporotic trigger. Mater. Sci. Eng., C 2014, $35,212-219$.

(51) Katsikogianni, M.; Missirlis, Y. F. Concise review of mechanisms of bacterial adhesion to biomaterials and of techniques used in estimating bacteria-material interactions. Eur. Cells Mater. 2004, 8, 37-57.

(52) Rochford, E. T. J.; Richards, R. G.; Moriarty, T. F. Influence of material on the development of device-associated infections. Clin. Microbiol. Infect. 2012, 18, 1162-1167.

(53) Karam, G.; Chastre, J.; Wilcox, M. H.; Vincent, J.-L. Antibiotic strategies in the era of multidrug resistance. Crit. Care 2016, 20, 136. 